DiRECTEUR DE LA PUBLICATION: Bruno David,

Président du Muséum national d'Histoire naturelle

RÉdACTEUR EN CHEF / EDITOR-IN-CHIEF: Didier Merle

ASSISTANTS DE RÉDACTION / AsSISTANT EDITORS: Emmanuel Côtez (geodiv@mnhn.fr); Anne Mabille

MISE EN PAGE / PAGE LAYOUT: Emmanuel Côtez

COMITÉ SCIENTIFIQUE / SCIENTIFIC BOARD:

Christine Argot (MNHN, Paris)

Beatrix Azanza (Museo Nacional de Ciencias Naturales, Madrid)

Raymond L. Bernor (Howard University, Washington DC)

Alain Blieck (chercheur CNRS retraité, Haubourdin)

Henning Blom (Uppsala University)

Jean Broutin (UPMC, Paris)

Gaël Clément (MNHN, Paris)

Ted Daeschler (Academy of Natural Sciences, Philadelphie)

Bruno David (MNHN, Paris)

Gregory D. Edgecombe (The Natural History Museum, Londres)

Ursula Göhlich (Natural History Museum Vienna)

Jin Meng (American Museum of Natural History, New York)

Brigitte Meyer-Berthaud (CIRAD, Montpellier)

Zhu Min (Chinese Academy of Sciences, Pékin)

Isabelle Rouget (UPMC, Paris)

Sevket Sen (MNHN, Paris)

Stanislav Štamberg (Museum of Eastern Bohemia, Hradec Králové)

Paul Taylor (The Natural History Museum, Londres)

COUVERTURE / COVER

Background: made from the Figures of the article; medallion: Jean-Claude Rage, to whom this issue is dedicated.

Geodiversitas est indexé dans / Geodiversitas is indexed in:

- Science Citation Index Expanded (SciSearch $\left.{ }^{\circledR}\right)$

- ISI Alerting Services ${ }^{\circledR}$

- Current Contents ${ }^{\circledR} /$ Physical, Chemical, and Earth Sciences ${ }^{\circledR}$

- Scopus ${ }^{\circledR}$

Geodiversitas est distribué en version électronique par / Geodiversitas is distributed electronically by:

- BioOne ${ }^{\circledR}$ (http://www.bioone.org)

Les articles ainsi que les nouveautés nomenclaturales publiés dans Geodiversitas sont référencés par / Articles and nomenclatural novelties published in Geodiversitas are referenced by:

- ZooBank ${ }^{\circledR}$ (http://zoobank.org)

Geodiversitas est une revue en flux continu publiée par les Publications scientifiques du Muséum, Paris Geodiversitas is a fast track journal published by the Museum Science Press, Paris

Les Publications scientifiques du Muséum publient aussi / The Museum Science Press also publish:

Adansonia, Zoosystema, Anthropozoologica, European Journal of Taxonomy, Naturae, Cryptogamie sous-sections Algologie, Bryologie, Mycologie.

Diffusion - Publications scientifiques Muséum national d'Histoire naturelle

CP $41-57$ rue Cuvier F-75231 Paris cedex 05 (France)

Tél. : 33 (0)1407948 05 / Fax: 33 (0)14079 3840

diff.pub@mnhn.fr / http://sciencepress.mnhn.fr

(C) Publications scientifiques du Muséum national d'Histoire naturelle, Paris, 2019

ISSN (imprimé / print): 1280-9659/ ISSN (électronique / electronic): 1638-9395 


\title{
Fossil dipsadid snakes from the Guadeloupe Islands (French West-Indies) and their interactions with past human populations
}

\author{
Corentin BOCHATON \\ Max Planck Institute for the Science of Human History, \\ Kahlaische Straße 10, D-07745, Jena (Germany) \\ and Laboratoire Archéozoologie et Archéobotanique: Sociétés, Pratiques et Environnements, \\ UMR 7209 - CNRS, MNHN - Muséum national d'Histoire naturelle, Sorbonne Université, \\ case postale 56, 57 rue Cuvier, F-75231 Paris cedex 05 (France) \\ and Institut de Systématique, Évolution, Biodiversité ISYEB \\ UMR 7205 - CNRS, MNHN, EPHE - Muséum national d'Histoire naturelle, Sorbonne Université, \\ 57 rue Cuvier, case postale 30, F-75231 Paris cedex 05 (France) \\ bochaton@shh.mpg.de (corresponding author)
}

Renaud BOISTEL Institut international de Paléoprimatologie et de Paléontologie humaine, UMR 7262 - CNRS, Université de Poitiers, UFR SFA - Bât. B35, 6 rue Michel Brunet, TSA 51106, F-86073 Poitiers (France)

Sandrine GROUARD Laboratoire Archéozoologie et Archéobotanique: Sociétés, Pratiques et Environnements, UMR 7209 - CNRS, MNHN - Muséum national d'Histoire naturelle, Sorbonne Université, case postale 56, 57 rue Cuvier, F-75231 Paris cedex 05 (France)

Ivan INEICH

Institut de Systématique, Évolution, Biodiversité ISYEB - UMR 7205 - CNRS, MNHN, EPHE, Muséum national d'Histoire naturelle, Sorbonne Université, 57 rue Cuvier, case postale 30, F-75231 Paris cedex 05 (France)

Anne TRESSET†

Salvador BAILON

Laboratoire Archéozoologie et Archéobotanique: Sociétés, Pratiques et Environnements, UMR 7209 - CNRS, MNHN - Muséum national d'Histoire naturelle, Sorbonne Université, case postale 56, 57 rue Cuvier, F-75231 Paris cedex 05 (France)

Submitted on 12 July 2018 | accepted on 28 January 2019 | published on 20 June 2019

urn:Isid:zoobank.org:pub:B0131324-1E7D-4D4E-97EA-AA812A5F7B94

Bochaton C., Boistel R., Grouard S., Ineich I., Tresset A. \& Bailon S. 2019. - Fossil dipsadid snakes from the Guadeloupe Islands (French West-Indies) and their interactions with past human populations., in Steyer J.-S., Augé M. L. \& Métais G. (eds), Memorial Jean-Claude Rage: A life of paleo-herpetologist. Geodiversitas 41 (12): $501-523$. https://doi.org/10.5252/geodiversitas2019v41a12. http://geodiversitas.com/41/12

\section{ABSTRACT}

Snakes of the family Dipsadidae Bonaparte, 1838 still occur on most of the Lesser Antillean islands, although they have been strongly impacted by modern and historical anthropogenic disturbances as it has been demonstrated for many squamate taxa worldwide. However, these observations mostly rely on modern assemblages, whereas the fossil record of dipsadid snakes, which is the most direct 


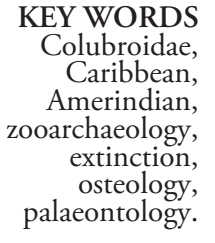

\author{
MOTS CLÉS \\ Colubroidae, \\ Caraïbe, \\ Amérindien, \\ archéozoologie, \\ extinction, \\ ostéologie, \\ paléontologie.
}

way to assess their past diversity, remains largely understudied. In order to fill this gap we performed a comprehensive review of the dipsadid snake fossils recovered on the Guadeloupe Islands. We identify the fossils on the basis of both qualitative osteological criteria and a morphometric study of the vertebrae. These approaches allow us to recognize three different dipsadid snake taxa, two of which still occur nowadays in Guadeloupe, but have been partly extirpated: Alsophis antillensis (Schlegel, 1837) and Erythrolamprus juliae cf. copeae (Parker, 1936), and a third one that is now extinct (Alsophis sp. 2). In addition, we evaluate previous interpretations of occurrences of snake remains in archaeological deposits. Our conclusions raise questions about the putative consumption of snake meat by past Amerindian populations, which is still far from being clearly demonstrated.

\begin{abstract}
RÉSUMÉ
Les serpents dipsadidés fossiles des îles de Guadeloupe (Antilles françaises) et leurs interactions avec les populations humaines du passé.

Les serpents de la famille des Dipsadidae Bonaparte, 1838 sont encore présents sur de nombreuses îles des Petites Antilles bien qu'ayant été, comme de nombreux squamates dans le monde, fortement impactés par les perturbations anthropiques actuelles et historiques. Cependant, en ce qui concerne les dipsadidés, l'évaluation de cet impact repose essentiellement sur les données issues des faunes actuelles, et le registre fossile de ces animaux, qui serait le plus à même de documenter leur diversité passée, demeure largement sous-évalué. Cette étude tente de contribuer à combler ce manque grâce à une large révision du matériel fossile de Dipsadidae découvert dans les îles de l'archipel de Guadeloupe. Nous tentons d'identifier ces restes fossiles par des approches en ostéologie qualitative et une étude morphométrique des vertèbres. Ces approches permettent la mise en évidence de trois taxons de Dipsadidae. Deux d'entre eux existent encore en Guadeloupe aujourd'hui, malgré des disparitions locales : Alsophis antillensis (Schlegel, 1837) et Erythrolamprus juliae cf. copeae (Parker, 1936). Le troisième étant éteint de nos jours (Alsophis sp. 2). Nous avons, de plus, conduit une étude archéozoologique dans le but de discuter les interprétations possibles de la présence de restes de serpents dans les dépôts archéologiques. Nos conclusions mettent en doute la possibilité d'une consommation des serpents par les populations précolombiennes de Guadeloupe.
\end{abstract}

\section{INTRODUCTION}

The current biodiversity crisis impacting worldwide faunas is now broadly accepted as a reality (Barnosky et al. 2011; Ceballos et al. 2015), as is its strong negative impact on insular faunas (Case et al. 1992; Steadman et al. 2015; Johnson et al. 2017). The extent of this phenomenon is difficult to quantify for extinctions that could have occurred in the past before contemporary recording and description of taxa. This is especially true for fragile insular ecosystems that are strongly impacted by numerous anthropic phenomena. One of the ways to asses these putative past extinctions is to study historical sources describing past biodiversity and/or available fossil evidence. Concerning fossil remains, the study of animal remains collected in archaeological deposits allows, in addition to documenting past fauna and its geographical distribution, the investigation of past interactions between humans and animals. This material is thus of crucial interest for studying how of human populations have reshaped past and current biodiversity (Vigne 1992; Crabtree 2016).

These questions have already been extensively studied on the Guadeloupe Islands (French West-Indies) where archaeological and paleontological deposits have providedevidence of the minor impact on past faunas by the pre-Columbian Amerindians, followed by the numerous extirpations and/or extinctions events occurring after the colonization of the Guadeloupe Islands by European settlers (Grouard 2001a; Boudadi-Maligne et al. 2016;
Stoetzel et al. 2016; Bochaton et al. 2019). Among all taxonomic groups that occurred in the past on Guadeloupe Islands, squamates are the most investigated and a significant amount of data concerning their past diversity exist from both historical (Du Tertre 1654; de Rochefort 1658) and paleontological (Bochaton et al. 2016a, b; 2017a) sources. However, our understanding of Guadeloupe's past squamate biodiversity and of its interactions with past human populations is incomplete, because the putative rich Guadeloupe past snake diversity remains poorly investigated. Indeed, although historical texts describing the past Guadeloupe snake fauna exist (see review in Breuil 2002), the morphology of their fossil remains as well as the interactions of these taxa with past Guadeloupe human populations have never been fully investigated. The sole exception to this lack of investigation concerns the remains of the boid snake, Boa blanchardensis Bochaton \& Bailon, 2018, recovered in Pleistocene layers on Marie-Galante Island (Bochaton \& Bailon 2018). Preliminary morphological studies of recently discovered dipsadid remains on La Désirade (Boudadi-Maligne et al. 2016) and Marie-Galante islands (Bailon et al. 2015; Bochaton et al. 2015) have already been carried out. However, most of these snake remains could not be identified at the species level. This makes dipsadid snakes, although being mentioned in several studies, among the less known groups having a fossil record on the Guadeloupe Islands. This is especially problematic considering that comparisons of historical sources with current biodiversity data raise several questions about past 


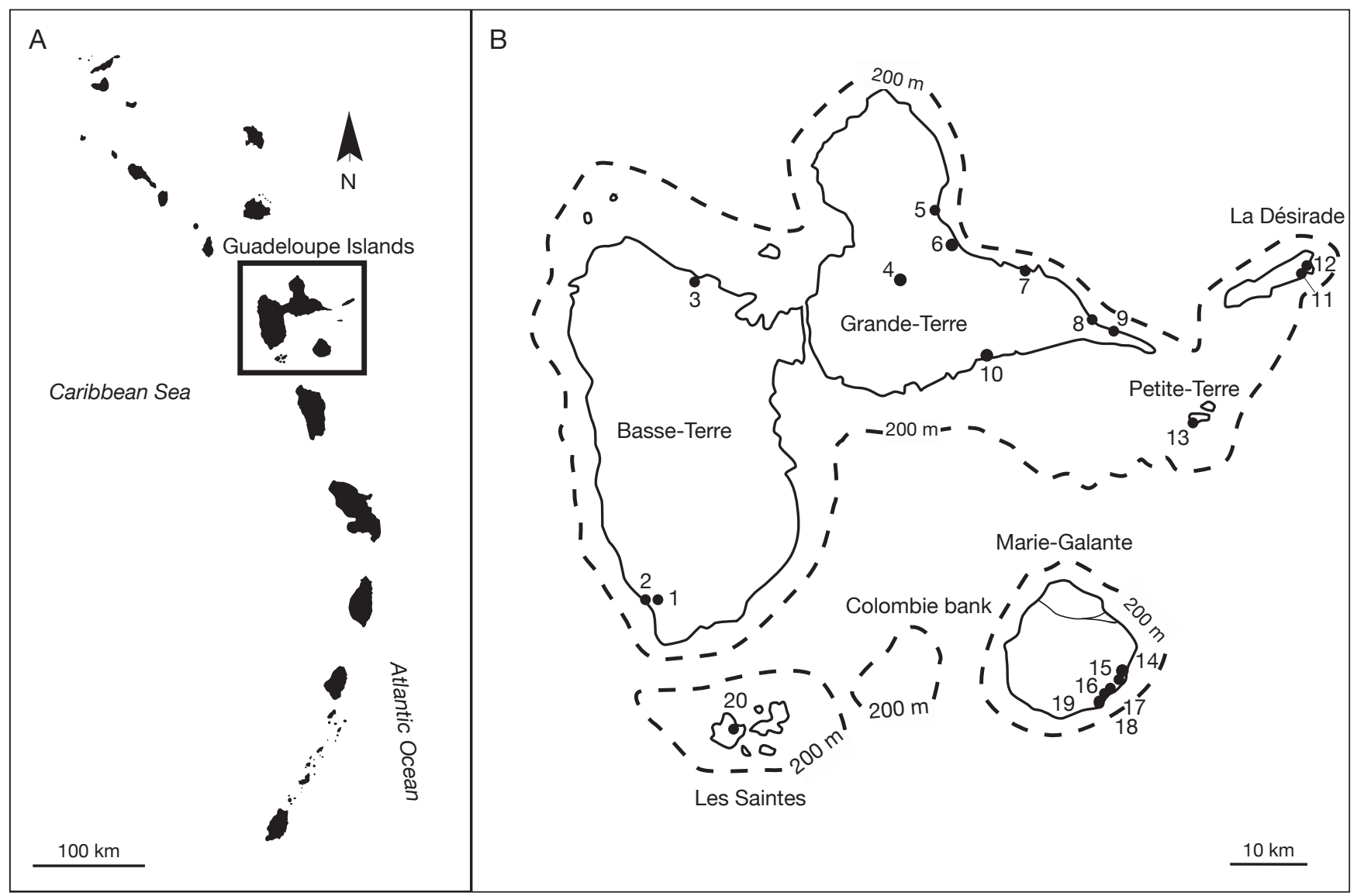

FIG. 1. - A, Map of the Lesser Antilles indicating the position of the Guadeloupe archipelago; B, Map of the Guadeloupe Islands with isobaths (-200 m) from Münch et al. (2013) and locations of the studied sites: 1, cathédrale de Basse-Terre; 2, gare maritime de Basse-Terre; 3, Sainte-Rose la Ramée; 4,Trou Lolo; 5, Anse à l'Écu cave; 6 , Bambous cave; 7, Morel; 8, Anse à la Gourde cave; 9 , Anse à la Gourde; 10, Pointe du Helleux; 11, Anse Petite Rivière; 12, Pointe Gros Rempart 6; 13, Caille à Bélasse; 14, Jean-François gully cave; 15, Morne Rita; 16, Tourlourous-Stade José Bade; 17, Blanchard cave; 18, Cadet 2 cave; 19, Cadet 3 shelter; 20 , Grande-Anse de Terre de Bas.

Guadeloupe snake diversity. Indeed, the snake fauna seems to have been far more diverse in the 17th century than nowadays. The text of R. P. Jean-Baptiste Du Tertre (1654), a French pastor who provided one of the first descriptions of Lesser Antillean fauna, indicates the occurrence of three different forms of possible dipsadid snakes on the Guadeloupe Islands. However, the situation nowadays is very different because, among the six main islands of this archipelago, three lack any dipsadid snakes (Marie-Galante, and La Désirade islands, and Petite-Terre islets), one is occupied by a single species (Les Saintes islets), and two are occupied by two species (Grande-Terre and Basse-Terre islands) (Powell \& Henderson 2012). Striking differences between historical and modern data could be another demonstration of the severe extinction crisis impacting Guadeloupe squamates during modern times. However, historical accounts often lack precision, which makes it challenging to deduce what happened to Guadeloupe snakes during the last centuries.

The aim of this study is to fill the scientific gap between historical accounts and modern snake diversity data, in order to improve our understanding of how Guadeloupe snake faunas have changed acrossthe last thirty millennia. To achieve this goal we review dipsadid snake fossil remains collected in all known archaeological and paleontological deposits on Guadeloupe Islands, and provide detailed descriptions and rigorous taxonomic identifications. We also provide new data concerning the relationships between past snake fauna and pre-Columbian human populations by studying assemblages of bones discovered in several archaeological contexts.

\section{REGIONAL SETTING}

\section{GUADELOUPE ISLANDS}

The Guadeloupe Islands are located in the Lesser Antilles, north of Dominica and south of Montserrat Islands (Fig. 1A). This archipelago (Fig. 1B) is composed of two large islands, BasseTerre $\left(848.1 \mathrm{~km}^{2}\right)$ and Grande-Terre $\left(585.7 \mathrm{~km}^{2}\right)$, separated by a $70 \mathrm{~m}$ wide marine channel 5-10 meters deep. Other islands nowadays are separated from the two main islands: La Désirade $\left(21.1 \mathrm{~km}^{2}\right)$, Petite-Terre islets $\left(1.5 \mathrm{~km}^{2}\right)$, MarieGalante $\left(157.5 \mathrm{~km}^{2}\right)$, and Les Saintes $\left(14.2 \mathrm{~km}^{2}\right)$ (Fig. 1B). These islands have different geological histories but, during interval covered by this study (Late Pleistocene to present), the configuration of the archipelago was similar to today except that Basse-Terre, Grande-Terre, La Désirade, and Petite-Terre islands were connected to form a unique landmass during the Late Pleistocene, when the sea level was $200 \mathrm{~m}$ lower (Fig. 1B) (Münch et al. 2013). 
TABLE 1. - Number of fossil bones and taxonomic attribution of dipsadid snakes bones collected in each archaeological and paleontological deposit on the Guadeloupe Islands.

\begin{tabular}{|c|c|c|c|c|c|c|c|}
\hline Islands & $\begin{array}{l}\text { Archaeological/ } \\
\text { Palaeontological sites }\end{array}$ & $\begin{array}{c}\text { Alsophis } \\
\text { antillensis } \\
\text { (Schlegel, } \\
\text { 1837) }\end{array}$ & $\begin{array}{l}\text { Alsophis } \\
\text { sp. } 2\end{array}$ & $\begin{array}{l}\text { Alsophis } \\
\text { sp. }\end{array}$ & $\begin{array}{l}\text { Erythrolamprus } \\
\text { juliae cf. } \\
\text { copeae }\end{array}$ & $\begin{array}{l}\text { Colubroidea } \\
\text { ind. }\end{array}$ & Total \\
\hline Les Saintes & Grande Anse Terre de Bas & 88 & 16 & 71 & 0 & 0 & 175 \\
\hline Grande-Terre & $\begin{array}{l}\text { Anse à la Gourde } \\
\text { Anse à l'Écu Cave } \\
\text { Anse à la Gourde Cave } \\
\text { Bambous Cave } \\
\text { Morel } \\
\text { Pointe du Helleux } \\
\text { Trou Lolo }\end{array}$ & $\begin{array}{r}42 \\
3 \\
20 \\
55 \\
6 \\
4 \\
2\end{array}$ & $\begin{array}{l}1 \\
0 \\
0 \\
0 \\
6 \\
3 \\
1\end{array}$ & $\begin{array}{l}4 \\
9 \\
3 \\
0 \\
9 \\
1 \\
0\end{array}$ & $\begin{array}{l}0 \\
4 \\
0 \\
0 \\
0 \\
0 \\
1\end{array}$ & $\begin{array}{r}3 \\
5 \\
11 \\
0 \\
0 \\
0 \\
0\end{array}$ & $\begin{array}{r}50 \\
21 \\
34 \\
55 \\
21 \\
8 \\
4\end{array}$ \\
\hline Basse-Terre & $\begin{array}{l}\text { Cathédrale de Basse-Terre } \\
\text { Gare Maritime de Basse-Terre } \\
\text { Sainte-Rose La Ramée }\end{array}$ & $\begin{array}{l}19 \\
69 \\
16\end{array}$ & $\begin{array}{l}1 \\
0 \\
0\end{array}$ & $\begin{array}{l}2 \\
1 \\
5\end{array}$ & $\begin{array}{l}0 \\
0 \\
1\end{array}$ & $\begin{array}{l}1 \\
2 \\
0\end{array}$ & $\begin{array}{l}23 \\
72 \\
22\end{array}$ \\
\hline La Désirade & $\begin{array}{l}\text { Anse Petite Rivière } \\
\text { Pointe Gros Rempart } 6\end{array}$ & $\begin{array}{l}11 \\
57\end{array}$ & $\begin{array}{l}2 \\
0\end{array}$ & $\begin{array}{r}9 \\
11 \\
\end{array}$ & $\begin{array}{l}0 \\
0\end{array}$ & $\begin{array}{r}0 \\
10 \\
\end{array}$ & $\begin{array}{l}22 \\
78 \\
\end{array}$ \\
\hline Petite-Terre & Caille à Bélasse & 4 & 0 & 4 & 0 & 4 & 12 \\
\hline Marie-Galante & $\begin{array}{l}\text { Cadet } 2 \text { Cave } \\
\text { Cadet } 3 \text { Shelter } \\
\text { Blanchard Cave } \\
\text { Morne Rita Cave } \\
\text { Jean-Francois gully Cave } \\
\text { Tourlourous, Stade José Bade }\end{array}$ & $\begin{array}{r}72 \\
64 \\
227 \\
66 \\
1 \\
14\end{array}$ & $\begin{array}{r}2 \\
4 \\
12 \\
0 \\
0 \\
3\end{array}$ & $\begin{array}{r}76 \\
54 \\
722 \\
52 \\
1 \\
15\end{array}$ & $\begin{array}{l}0 \\
0 \\
0 \\
0 \\
0 \\
0\end{array}$ & $\begin{array}{r}0 \\
4 \\
78 \\
9 \\
0 \\
1\end{array}$ & $\begin{array}{r}150 \\
126 \\
1039 \\
127 \\
2 \\
33\end{array}$ \\
\hline & Total & 840 & 51 & 1049 & 6 & 128 & 2074 \\
\hline
\end{tabular}

\section{GUADELOUPE DIPSADID SNAKES}

Concerning the Guadeloupe snake fauna, three dipsadid species currently occurs in the archipelago. The first species, Alsophis antillensis (Schlegel, 1837) is a medium sized snake reaching a maximum total length of $129 \mathrm{~cm}$ (Duméril et al. 1854). This species currently occurs on Grande-Terre and Basse-Terre Islands (Breuil et al. 2009; Powell \& Henderson 2012). A specimen of this species was also collected in 1839 by Hotessier (MNHN-RA-0.3555) on Marie-Galante from where it is absent nowadays (Breuil 2002). This snake is also described by Du Tertre $(1654,1667)$ who reported the occurrence of three different non-venomous snakes on the Guadeloupe Islands during the $17^{\text {th }}$ century. One of these snakes is described as a grass snake about five $(160 \mathrm{~cm})$ or six $(190 \mathrm{~cm})$ feet in length with a black and yellow back, and a grey and yellow belly. This snake probably corresponds to A. antillensis. That species includes two varieties that only differ by their coloration according to Duméril et al. (1854). The "A variety" is similar to the one described by Du Tertre (1667) but the "B variety" is completely black (Duméril et al. 1854). This fact become interesting in regard with the second snake described by Du Tertre (1667) in Guadeloupe, a large snake measuring more than seven feet $(224 \mathrm{~cm})$ in total length and completely black just as the "B variety" of $A$. antillensis. Still, the small size of the black $A$. antillensis $(120 \mathrm{~cm}$ of total length) does not match the size of the large snake described by Du Tertre (1667).

The second species currently occurring on Guadeloupe is Alsophis sanctonum Barbour, 1915, a species only reported from Les Saintes islands. This species was long considered a subspecies of $A$. antillensis, but was elevated to species level by Breuil (2002). The last dipsadid species currently occurring in Guadeloupe is Erythrolamprus juliae (Cope, 1879). This snake still occurs nowadays on Grande-Terre and Basse-Terre islands where it is represented by the subspecies $E$. $j$. copeae (Parker, 1936). This snake historically also occurred on MarieGalante where a specimen of a distinct endemic sub-species was described as E. j. mariae (Barbour, 1914), but apparently went extinct during the 19 $9^{\text {th }}$ century (Henderson 1992; Breuil 2002). This taxon was also probably described by Du Tertre who wrote about a small grey grass snake never exceeding two feet $(64 \mathrm{~cm})$ or two feet and half $(81 \mathrm{~cm})$ of length and occurring throughout the Guadeloupe Islands (Du Tertre 1654, 1667). The two dipsadid genera occurring on Guadeloupe have different geographical origins, with Alsophis Fitzinger, 1843 having colonized the Lesser Antilles from the Greater Antilles and Erythrolamprus from continental South America (Hedges 1996; Hedges et al. 2009).

\section{GUADELOUPE PAST HUMAN PEOPLING}

The oldest direct evidence for the occurrence of humans on Guadeloupe is provided by the archaeological site of Morel Zero on Grande-Terre Island (Paulet-Locard \& Stouvenot 2005), dated to around $1500 \mathrm{BC}$ (Mesoindian or Archaic Age), but indirect evidences of far older human occupation are dated to around $3000 \mathrm{BC}$ on Marie-Galante Island (Stouvenot et al. 2014; Siegel et al. 2015). The oldest site containing ceramic remains is the site of Morel I on GrandeTerre. It is dated from around $80 \mathrm{AD}$, and is attributed to the Saladoid cultures (Neoindian or Early Ceramic Age) (Clerc 
A Alsophis rijgersmaei
MNHN-ZA-AC 2016-9
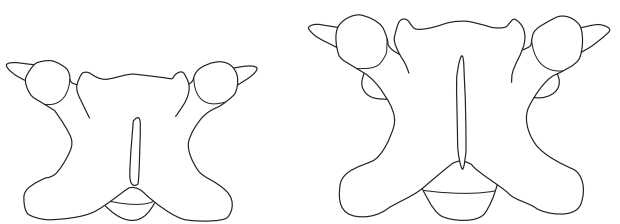

Dorsal view
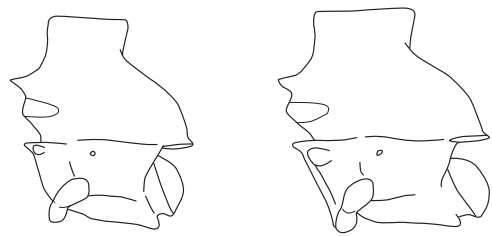

Left lateral view
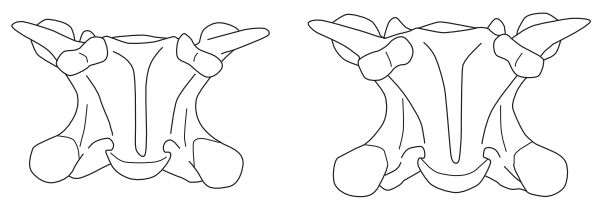

Ventral view

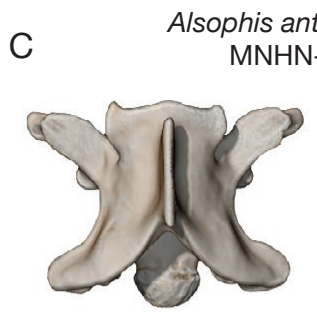

ensis variety

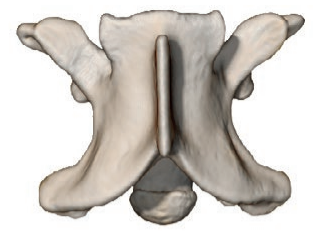

Dorsal view
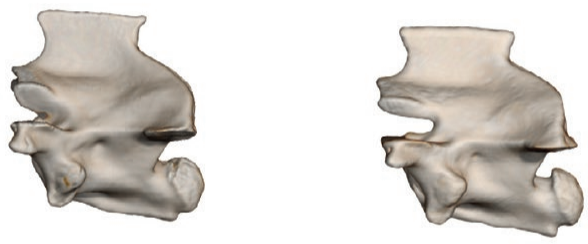

Left lateral view

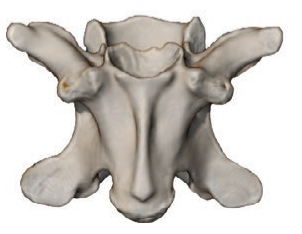

Ventral view

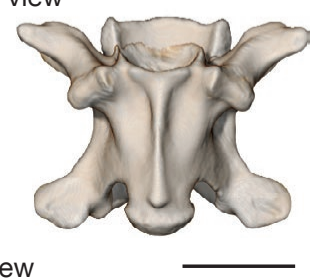

B

Alsophis rijgersmaei MNHN-UMR7209 406

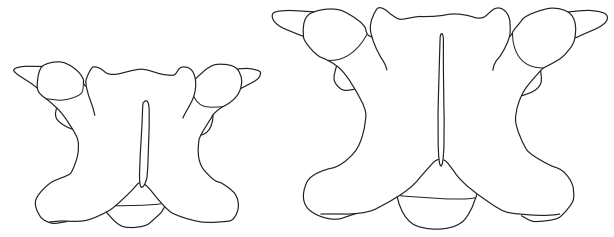

Dorsal view
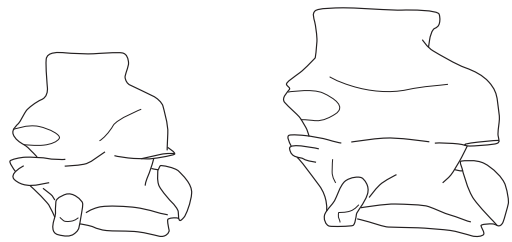

Left lateral view

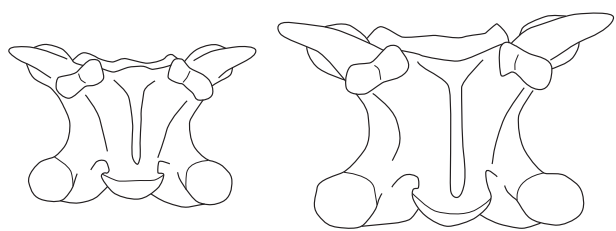

Ventral view

D Alsophis antillensis variety A MNHN-UMR7209601

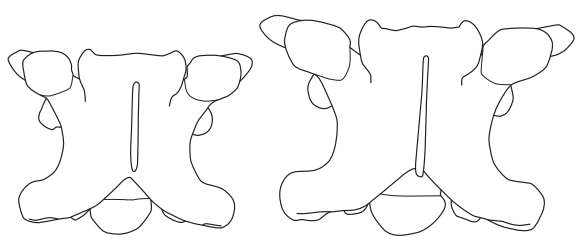

Dorsal view
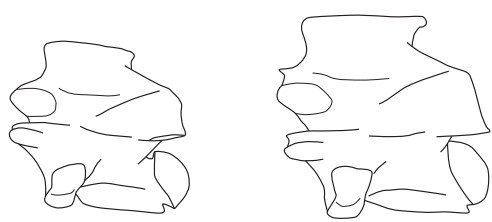

Left lateral view

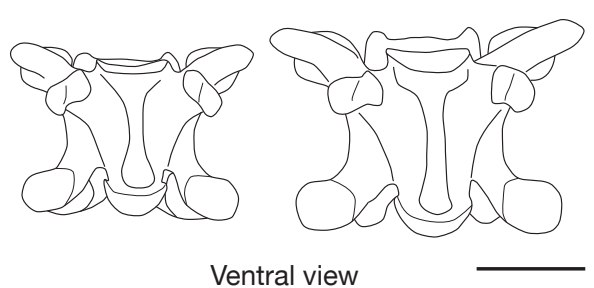

FIG. 2. - Morphological variability among four specimens of Alsophis Fitzinger, 1843. From left-to-right: smallest and largest available specimens of Alsophis rijgersmaei Cope, 1869 and Alsophis antillensis (Schlegel, 1837) varieties A and B (of Duméril et al. 1854). The two figured vertebrae for each specimen correspond to the most different morphologies observed among the trunk vertebrae (anterior vertebra on the left and median vertebra on the right).

1964; Hofman et al. 1999; Bérard 2013; Fitzpatrick 2015). This first ceramic culture later developed into Troumassoid cultures (900 AD-1500 AD) (Late Ceramic Age) (Bonnissent
2008; Keegan et al. 2013; Honoré 2014). After a period of cohabitation with Amerindians, the French colonization of Guadeloupe started in 1635 and led to the disappearance of 
Amerindian populations (Saunders 2005; Keegan et al. 2013) and to the industrialization of the islands. As a consequence, nearly all primary forests on the islands were destroyed in the $18^{\text {th }}$ century (Lasserre 1961).

\section{MATERIAL AND METHODS}

\section{FOSSIL DIPSADID MATERIAL AND ANATOMICAL NOMENCLATURE}

Studied fossil material consist of 2074 dipsadid snake remains collected from 20 archaeological and paleontological deposits located on most of the islands of Guadeloupe (Fig. 1B). These deposits are mostly dated from pre-Columbian times with the exception of Marie-Galante paleontological deposits (Cadet 2 cave, Cadet 3 shelter and Blanchard cave) which contain layers dated from the Late Pleistocene to Late Holocene. The sites of Jean-François gully, Bambous, and Trou Lolo caves are modern deposits. Details and bibliographies concerning these deposits can be found in supplementary materials.

The studied fossil material is stored in the repository of the "Service régional de l'archéologie de Guadeloupe" (BasseTerre/Guadeloupe) at the exception of the material from Blanchard Cave that is stored in the "Musée archéologique Edgard Clerc" (Grande-Terre/Guadeloupe). As it is the standard for archaeological faunal remains, bones were not be given an individual collection number but are ordered in the collections following their site of origin and their stratigraphic position. For this reason we indicated the site and the stratigraphic origin of each pictured specimen.

The anatomical nomenclature used mostly follows Cundall \& Irish (2008) for the skull. The nomenclature for vertebrae follows Hoffstetter \& Gasc (1969) and Szyndlar (1984).

\section{COMPARATIVE MATERIAL OF MODERN DIPSADID SNAKES}

The comparative sample used in this study consists of 18 museum specimens of Lesser-Antillean dipsadid snakes belonging to three Alsophis species, one Clelia species, and two Erythrolamprus species from: the Museum of Comparative Zoology (Boston, USA) (MCZ), Florida Museum of Natural History, University of Florida (Gainesville, USA) (UF), and the Muséum national d'Histoire naturelle (Paris, France) Herpetology (MNHN-RA), Comparative Anatomy (MNHN-ZA-AC), and UMR7209 Laboratory (coll. UMR7209) collections (see Appendix 1). In addition we performed an X-Ray Microtomography (XMT) of the type specimen of the now-extinct "B variety" of Alsophis antillensis collected in Guadeloupe (MNHN-RA-0.3556). The specimen of $A$. antillensis (coll. UMR7209 601) was the sole specimen for which we had pictures before osteological preparation. It corresponds to the previously defined "A variety" of the species. The scarcity of skeletons of Lesser Antillean dipsadid snakes in museum collections did not allow including more comparative specimens in this study.

In order to observe the intra-individual and ontogenetic variability of the trunk vertebrae in the genus Alsophis, we selected four specimens corresponding to two closely related species (Fig. 2), Alsophis rijgersmaei Cope, 1869 (coll. UMR7209 406 and MNHN-ZA-AC 2016-9) and Alsophis antillensis (coll. UMR7209 601 and MNHN-RA-0.3556). This choice was strongly constrained by the limited availability of comparative specimens. The full ontogenetic variability could not be described using specimens of a single species.

\section{X-ray microtomography (XMT)}

The XMT of Alsophis antillensis (MNHN-RA-0.3556: Fig. 2) was performed according to the protocols reported in the literature (Boistel et al. 2011; Lauridsen et al. 2011; Zanette et al. 2013). We used an EasyTom XL duo RX solution scanner at the Centre for Microtomography of the University of Poitiers (France). Scans were performed at $100 \mathrm{kV}$ and $34 / 32 \mathrm{~mA}$. The geometry was set to obtain a $38.59 \mu \mathrm{m}$ voxel size in the reconstructed three-dimensional images. The reconstruction was performed using the FDK algorithms of Xact ver. 1.1 (revision $=6663 \mathrm{M}$, RXsolution, acceleration in GPU). The dataset consists of 4320 projections taken over $360^{\circ}$ on the whole body of the specimen. Direct volume rendering was used to visualize the sub-set of selected voxels of the skeleton in AVIZO v. 7.1 and 6.1 (FEI Visualization Sciences Group, http://www.fei.com) after having used the software IMAGEJ to mask the anatomical structures not useful for the present study.

\section{Morphometric analysis}

A maximum of eight measurements (depending on bone fragmentation) were taken on modern and fossil dipsadid snakes trunk vertebrae by a single user (CB) using a dial caliper (Mitutoyo IP 67). These measurements (Fig. 3) are mostly taken from Szyndlar (1984), Rage (2001), and Albino (2011) and are widely used in snake vertebral studies. Subsequent statistical analyses were performed using the R software (cran.r-project.org). Log-shape ratios (Mosimann \& James 1979) were calculated on the $\log 10$ transformed measurements. This manipulation allows the separation of shape and size components of the variables. A Principal Component Analysis (PCA) was then performed to explore the data. Linear Discriminant Analyses (LDA) and Mahalanobis distance trees were performed to observe the morphological distance separating the investigated taxa. These analyses were conducted using the R libraries MASS (Ripley et al. 2016) and Ape (Paradis \& Schliep 2018). Manova analyses were also performed using basic R Stats library. All probability values (p. value) were considered significant when inferior to 0.01 .

Two set of analyses using different numbers of fossil vertebrae were performed depending on the number of measurements available for fossil elements. For each comparative modern specimen, a maximum of 15 vertebrae representing all the morphological variability of trunk vertebrae were chosen on the basis of their morphology to be measured, except for some specimens for which only a limited number of vertebrae were available. We carried out a first analysis using the maximum number of fossil specimens (312) and 


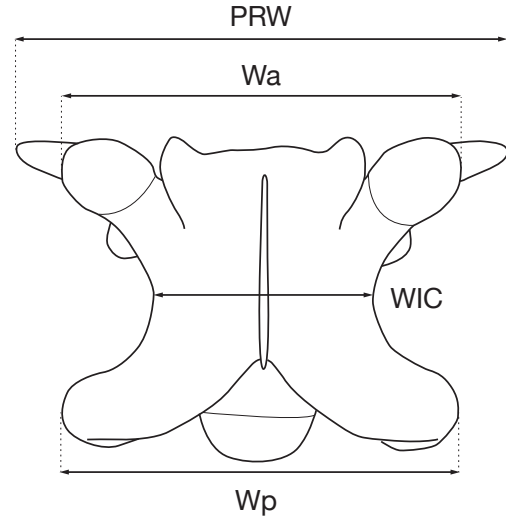

Dorsal view

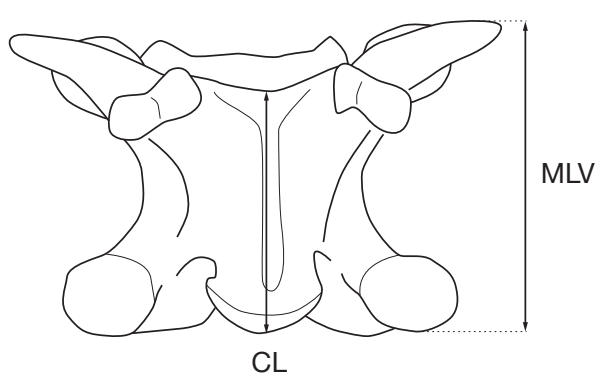

Ventral view

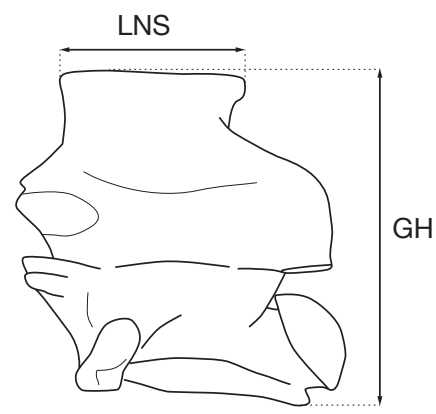

Lateral view

FIG. 3. - Measurements taken of snake vertebrae: CL, greatest centrum length; GH, greatest height of the vertebra; LNS, greatest length of the neural spine; MLV, maximum length of vertebra; PRW, prezygapophyseal width; WIC, width of interzygapophyseal constriction (= NAW sensu Szyndlar 1984); Wa, greatest width of the anterior part of the neural arch; Wp, greatest width of the posterior part of the neural arch (= PO-PO sensu Szyndlar 1984).

the minimum number of variables (four variables: CL, MLV, WIC, and Wp). The second analysis was performed using the minimum number of fossil specimens (100) and the maximum number of measurements (eight variables: CL, MLV, WIC, Wp, Wa, PRW, GH, and LNS). The first analysis focused on the distinction between Alsophis and Erythrolamprus vertebrae. It includes, in addition of all fossil specimens, the following comparative specimens: Alsophis antillensis morphotype A (coll. UMR7209 601), Alsophis rijgersmaei (coll. UMR7209 406, MNHN-ZA-AC 2016-9), Alsophis rufiventris (Duméril, Bibron \& Duméril, 1854) (MCZ R-76665, UF 15495), Erythrolamprus juliae copeae (MNHN-RA-1998.485) and Erythrolamprus perfuscus (Cope, 1862) (MCZ 78620). This first analysis is the only one including fossil and modern Erythrolamprus, because all measurements could not be obtained from fossil Erythrolamprus vertebrae. The second analysis using all the measurements is more focused on Alsophis vertebrae and only includes the above mentioned comparative specimens of this genus. The CT-scan of Alsophis antillensis morphotype B (MNHN-RA-0.3556) is not included in our morphometric analyses, because measurements could not be acquired using the same methodology as for other specimens and, thus, the data were not comparable.

\section{RESULTS}

\section{MORPHOLOGICAL VARIABILITY OF TRUNK VERTEBRAE WITHIN ALSOPHIS (FIG. 2)}

Medial constriction of the vertebrae varies within individuals along the vertebral column. The most striking differences appear on the zygosphene anterior margin, which can be trilobed or concave within the same individual. The length and height of the neural spine are also variable to some extent. In ventral view, the centrum may have more or less deep subcentral depressions, and the hemal keel can be of constant width or is wider in its posterior half. In lateral view, the ventral margin of the hemal keel can be nearly straight to strongly stepped. Centrum length (CL) of the trunk vertebrae in the same individual is also variable, with the largest vertebra being $115 \%$ of the CL of the smallest. Comparison of individuals of different sizes shows that the morphology of the prezygapophyseal processes undergoes an ontogenetic change from being slender and pointed on smaller specimens to being larger and blunted on larger specimens. The neural spine also changes ontogenetically. In lateral view, this structure is high and short on the smallest specimens and lower and longer on the largest specimens. The anterior and posterior margins of the neural spine also more strongly overhang the centrum on the largest specimens. In dorsal view, prezygapophyseal facets are more rounded on small specimens, versus ovoid on large specimens. In ventral view, the ventral edge of the hemal keel changes from sharp on small specimens to blunt on large specimens. These observations also demonstrate that clear morphological differences, free of potential intra-specific variability, between the vertebrae of Alsophis antillensis $\mathrm{A}$ and $B$ varieties are absent.

\section{SYSTEMATIC PALAEONTOLOGY}

Order SQUAMATA Oppel, 1811

Suborder SERPENTES Linnaeus, 1758

Family DiPSADIDAE Bonaparte, 1838

Subfamily Xenodontinae Cope, 1895

Genus Alsophis Fitzinger, 1843

Alsophis antillensis (Schlegel, 1837)

EXAMINED MATERIAL. - A total of 840 bones from all 20 sites and six islands are attributed to Alsophis antillensis (Table 1). Among these are 82 cervical and caudal vertebrae that could not be unambiguously identified because of their strong morphological variability. These elements, which are not described in this study, were associated with $A$. antillensis on the basis of their sizes, and the taxonomic composition of the snake material of the different sites. 


\section{DESCRIPTION}

\section{Maxilla (4 elements; Fig. 4A)}

The most complete maxilla only lacks its anterior tip. It bears 16 tooth positions and measures $15.6 \mathrm{~mm}$ in maximum length. Maxillae are elongate, slightly incurved in dorsal and ventral views, and bear well-developed ectopterygoid and palatine processes. In ventral view, a short diastema is visible below the ectopterygoid process and separates the two last dental positions from the previous ones. The few teeth preserved and size of teeth alveolar niches show that the two last teeth are larger than the others (tendency to opisthomegadont dentition), no other observation can be made regarding the structure of maxillary teeth. In dorsal view, the ectopterygoid process is of sub-rectangular shape and occurs medial to the second and third last dental positions. The ectopterygoid process is wide, moderately long, and ventrally incurved with a rounded medial margin. The palatine process occurs medial to the fifth and ninth first dental positions. Still in dorsal view, this process is of sub-triangular shape with a longer anterior than posterior margin. The bone has a shallow dorsal notch and a weakly marked insertion area for the maxillary ramus of the ectopterygoid situated at the posterior base of the ectopterygoid process (broken on the bone depicted in Fig. 4A).

\section{Palatine (1 element; Fig. 4B)}

The only available element is a complete right palatine discovered in Blanchard Cave. This bone measure $6.5 \mathrm{~mm}$ in maximum length and bears 14 tooth positions. In lateral view, the bone bears a long, sub-triangular, and ventro-posteriorly oriented maxillary process. The vomerine process (sensu Szyndlar 1984) is well-developed, long, and sub-rectangular shaped in lateral view. In dorsal view, the choanal process (sensu Szyndlar 1984) prolonges the vomerine process in medioventral direction and is slightly posteriorly incurved. The anterior and posterior tips of the bone are blunted and neither is bifurcated. In ventral view, a large foramen for the maxillary nerve (= palatine foramen sensu Cundall \& Irish 2008) is visible at the base of the maxillary process. The pterygoid process is short and bears a small ventral articular facet for contact with pterygoid bone.

\section{Pterygoid (3 elements; Fig. 4C, D)}

Three fragments of pterygoids corresponding to anterior (Fig. 4C) and posterior (Fig. 4D) parts of the bone are present in the studied assemblage. This bone is nearly flat in lateral view and anteriorly incurved in ventral view. Still in ventral view, on the medial edge of its anterior portion, the bone bears a row of 19 small and posteriorly incurved teeth. The posterior fragment of this bone (Fig. 4D) shows that at least the posterior one-third of the bone lacks teeth.
The ectopterygoid process is well developed, distinct,and lies in line with the $13^{\text {th }}$ to $19^{\text {th }}$ dental positions in ventral view. This process is subtriangular shaped with a blunt lateral margin in ventral view. The posterior part of the bone is elongate and its medial surface is concave in ventral view. In dorsal view, the posterior part of the bone bears a deep imprint of the mandibular condyle of the quadrate bone; this imprint is separated from the medial part of the bone by a high and thick pterygoid crest. The posterior tip of the bone is rounded and bears a small lateral notch that contacts the posterior process of the compound bone when the living animal closes its mouth (Cundall \& Irish 2008).

\section{Compound bone ( 3 elements; Fig. 4E)}

The two most complete compound bones are of two different sizes: the first one (Fig. 4E) is complete and measure $14 \mathrm{~mm}$ in maximum length, whereas the second one measure $28 \mathrm{~mm}$ long despite lacking its retroarticular process. The bone is elongate. The retroarticular process is well developed, longer than the glenoid fossa, of truncated conical shape, medially incurved in dorsal view, and perforated by a deep and large foramen near its anterior margin in medial view. In lateral view, the surangular crest is moderately developed with a nearly straight dorsal margin and a sharp ventral margin. The mental foramen is large, semi-circular, and opens anteriorly. In medial view, the development of the prearticular crest is variable, but this crest consistently is two times higher than the surangular crest on all specimens. In dorsal view, the mandibular fossa is long and deep, but its width varies. In medial view, the imprint of the angular is well marked and posteriorly pointed.

\section{Dentary (1 element; Fig. 4F)}

The only recovered dentary fragment corresponds to the posterior two-thirds of the bone. This fragment is moderately elongate and preserves seven tooth positions. In medial view, the Meckel groove is fully open with a narrower anterior opening that nearly reaches the anterior tip of the fragment. In lateral view, the bone has a large mental foramen situated in its median part. The bone bears a long posteroventral process with a blunted posterior apex. This process forms the ventral margin of a triangular insertion for the lateral process of the compound bone.

\section{Trunk vertebrae (741 elements; Fig. 5A, B)}

These vertebrae are weakly built and of variable size (centra lengths between 1 and $6.6 \mathrm{~mm}$ ) corresponding to all ontogenetic stages from juvenile to adult individuals. In dorsal view, vertebrae are slightly wider than long to slightly longer than wide $($ ratio $\mathrm{CL} / \mathrm{WIC}=0.81-1.17$ ) and exhibit a well-marked median constriction. The zygosphene is moderately wide and bears an anterior margin

FIG. 4. - Cranial bones of Alsophis antillensis (Schlegel, 1837) from La Désirade and Marie-Galante islands: A, right maxilla from Pointe Gros Rempart 6 (Dec. 7) located on La Désirade Island; B, right palatine from Blanchard Cave (Layer 8) located Marie-Galante Island; C, D, left pterygoid anterior (C) and posterior (D) fragments from Blanchard Cave (layers 8 and 10) located Marie-Galante Island; E, left compound bone from Blanchard Cave (Layer 8 ) located Marie-Galante Island; F, right dentary from Pointe Gros Rempart 6 (Dec. 3) located on La Désirade Island. Abbreviations: c. p., choanal process; d. $\mathbf{n}$., dorsal notch; di., diastema; e. p. m., ectopterygoid process of the maxilla; e. p. p., ectopterygoid process of the pterygoid; f. m. $\mathbf{n}$., foramen for the maxillary nerve; g. f., glenoid 


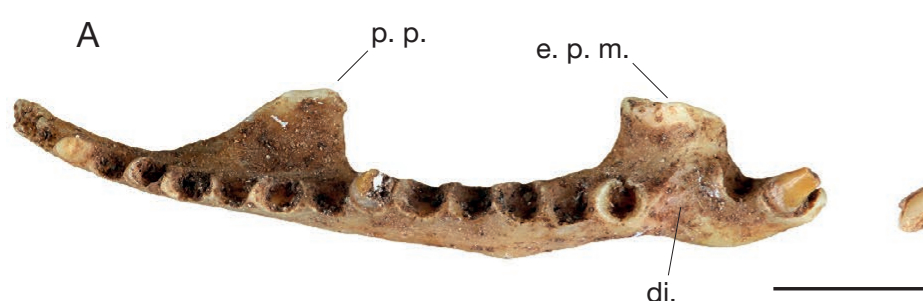

Ventral view

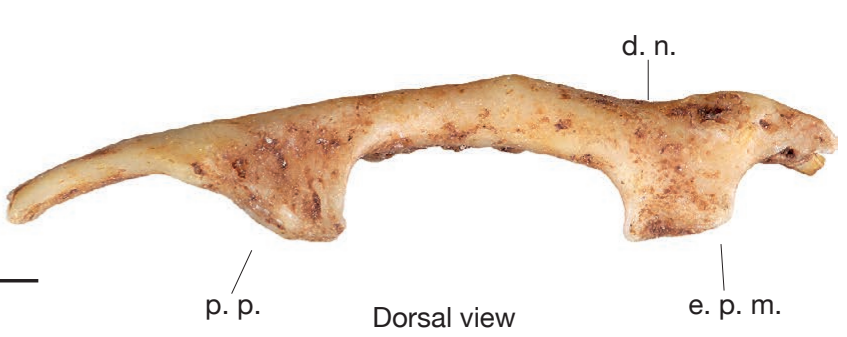

p. p.

Dorsal view

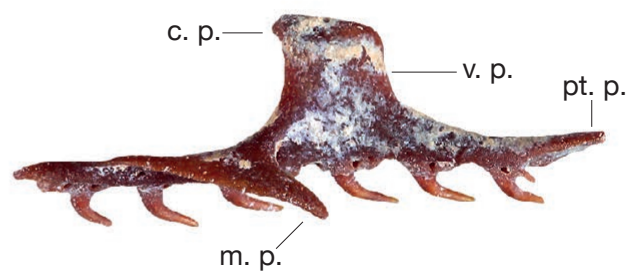

Lateral view

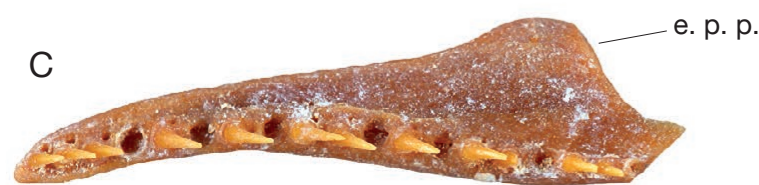

Ventral view

D

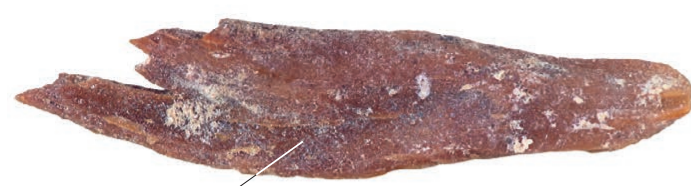

m. c.'
B

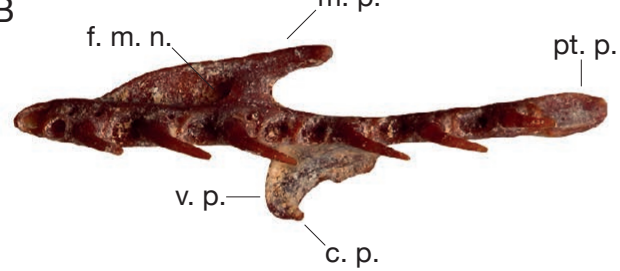

Ventral view

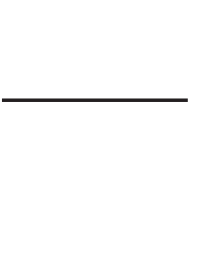

p. p.

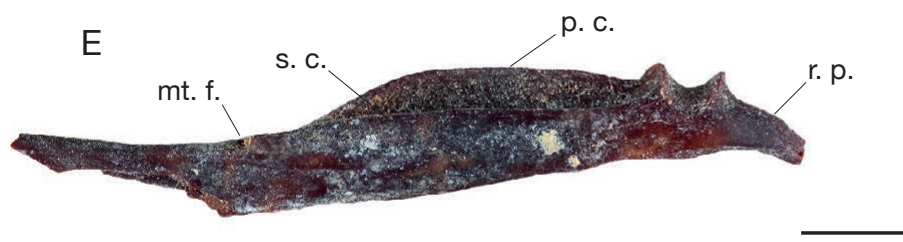

Lateral view
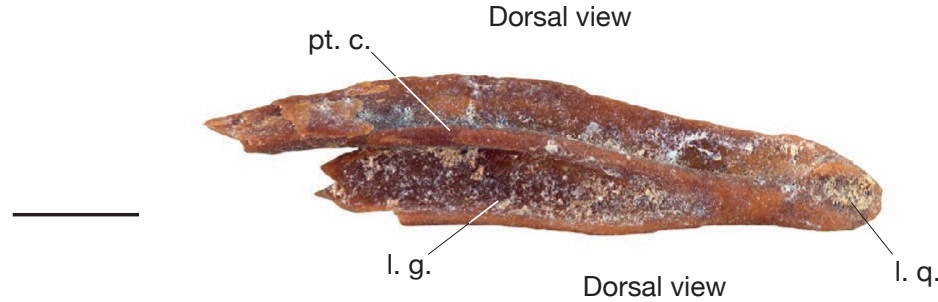

I. q.

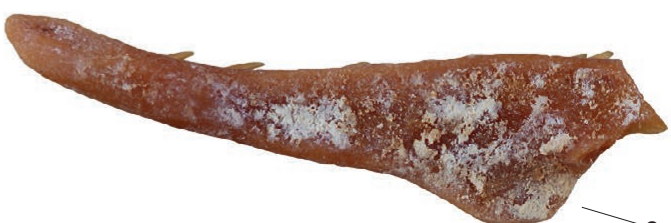

p. p.
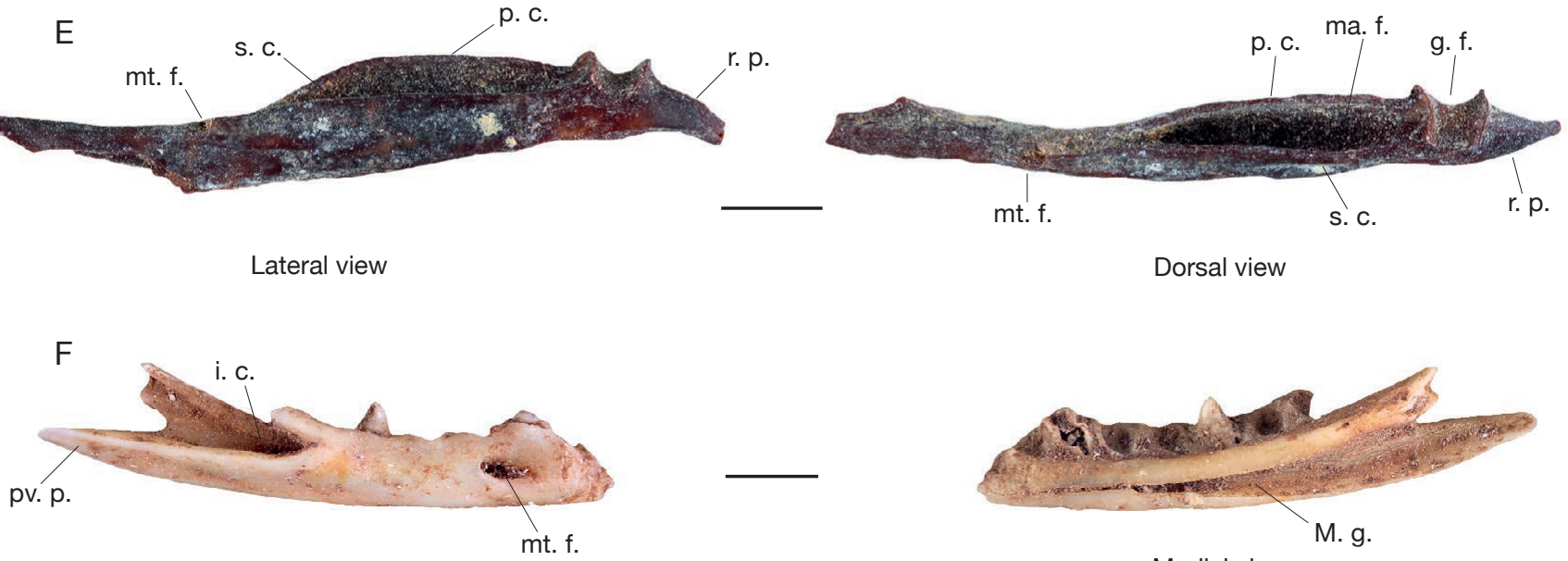

Lateral view

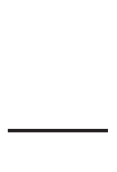

Dorsal view

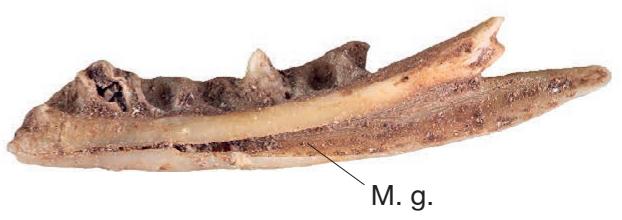

Medial view

fossa; i. c., insertion area for the lateral process of the compound bone; i. q., imprint of the mandibular condyle of the quadrate bone; I. g., lateral groove; m. c., medial concave surface; M. g., Meckel groove; m. p., maxillary process; ma. f., mandibular fossa; mt. f., mental foramen; p. c., prearticular crest; p. p., palatine process; pt. c., pterygoid crest; pt. p., pterygoid process; pv. p., posteroventral process; r. p., retroarticular process; s. c., surangular crest, v. p., vomerine process. Scale bars: $3 \mathrm{~mm}$. 
whose shape varies from straight to slightly trilobate. The postero-medial notch of the neural arch is moderately deep and bracketed by flared lateral margins forming an angle of nearly $90^{\circ}$. On some specimens, a very reduced and slightly marked epizygapophyseal spine occurs, but this is absent on most of the vertebrae, including the two figured examples. Prezygapophyseal facets are rounded to ovoid in outline. The morphology of the prezygapophyseal processes is highly variable depending on the size of the specimen. These processes are anterolaterally oriented and conical shaped on small specimens, but tend to become shorter, wider, and blunter in large specimens although remaining elongate in some. In lateral view, the shape of these processes also varies from a transversally rounded in small specimens to a flattened shape in large specimens. Still in lateral view, the neural spine is well developed and longer than high. In most specimens the neural spine is two times longer than high, but this condition is variable in our material. The anterior margin of the spine is usually slightly incurved and a small dorsal anterior projection slightly overhangs the anterior edge of the spine whereas the posterior margin more strongly overhangs the posterior edge of the spine. The interzygapophyseal crest is straight in lateral view. Synapophysis bear moderately distinct diapophysis and parapophysis, the first being slightly larger and located more posteriorly. The hemal keel is well-visible in lateral view. The hemal keel is well-extended ventrally except along its anterior part where it shallows progressively until reaching the cotyle. In ventral view, the hemal keel is laterally well-delimited, thin, and exhibits a more or less spatulate shape (sensu Holman 2000) with a posterior enlargement of variable extend. However, rare specimens instead have a hemal keel shaped like a gladius (sensu Holman 2000). The hemal keel appears to exhibit important morphological variability in the material, but it is always laterally well-delimited. Still in ventral view, the centrum is triangular with well-marked lateral margins. It has subcentral depressions of variable extend and depth. A subcentral foramen occurs to either side of the hemal keel. In anterior view, the roof of the zygosphene is thin, ranging from slightly curved to straight. Still in anterior view, the cotyle is generally subcircular and slightly wider than high. However, the cotyle is round on some specimens. The cotyle is bordered by paracotylar foramina and deep paracotylar depressions of low extension. In ventral view, the cotyle also bears sub-cotylar tubercles on some specimens. In posterior view, the neural arch is moderately vaulted. In posterior outline, the condyle ranges from subcircular(often slightly dorsoventrally flattened) to round. It is separated from the centrum by a well-marked precondylar constriction best seen in ventral view.

\section{REMARKS}

The above described bones have been associated together on the basis of their size and of several morphological characters. They exhibit several characters occurring in "colubrid" (sensu lato) snakes: a slightly curved maxilla having well-developed palatine and ectopterygoid processes, with the number of teeth (16) between two and 36 (Marx \& Rabb 1972), and with the two most posterior teeth larger than the others (Cundall \& Irish 2008); the occurrence of distinct maxillary and choanal processes on the palatine bone (Cundall \& Irish 2008); vertebrae are weakly build, with a thin zygosphene and neural spine, differentiated paradiaopophyses, paracotylar foramina, and well-developed prezygapophyseal processes (Rage 1984; Hsiou \& Albino 2010). The fossils also exhibit a character occurring in xenodontine snakes: the occurrence of an extension (choanal process) of the vomerine process of the palatine in postero-ventral direction (Cundall \& Irish 2008). Among the Lesser-Antillean xenondontine snakes, these fossils exhibit several differences compared to the genus Erythrolamprus (Erythrolamprus juliae). In the later genus: the maxilla has more teeth (25-26) and its palatine process bears a distinct, pointed, and posteriorly oriented distal tip; the pterygoid has posterior lateral and medial grooves that are less deep and extended, its ectopterygoid process is weakly separated from the pterygoid flange; and the compound bone is more elongate and has a shorter mandibular fossa. Additional differences also occurr on the trunk vertebrae (see below in description of fossil Erythrolamprus). By contrast, the fossil bones are entirely consistent with Alsophis antillensis, the second xenodontine species currently occurring on the Guadeloupe Islands. The fossils differ from other species of Alsophis we observed: on the compound bone the dorsal margin of the surangular crest is straight in medial view in $A$. antillensis and A. rijgersmaei, whereas it is slightly concave in $A$. rufiventris. The morphology of the vertebrae also is very different from A. rufiventris (see below in description of fossil Alsophis sp. 2) and also differs from $A$. rijgersmaei whose vertebrae bear a hemal keel consistently of gladius shape (sensu Holman 2000) with straight lateral margins and no posterior enlargement. In addition, gross size comparison with modern Alsophis specimens show that fossil vertebrae correspond to individuals between 25 and $150 \mathrm{~cm}$ in total length or between 18 and $112 \mathrm{~cm}$ in snout-vent length, a size matching that of modern $A$. antillensis (max. $93 \mathrm{~cm}$ of SVL see Henderson \& Powell 2009), although some fossils appear to be larger than modern representatives. On the basis of these observations and the current occurrence of $A$. antillensis on the Guadeloupe Islands, we refer these remains to Alsophis antillensis. Compared with the snakes previously identified from fossils on the Guadeloupe Islands, our fossils aresimilar to the cf. Alsophis sp. and Colubroidea sp. 1 of Bochaton et al. (2015) in Cadet 2 cave (Marie-Galante Island), to the cf. Alsophis and Colubroidea of Bailon et al. (2015) in Blanchard cave (Marie-Galante Island), and to the Alsophis sp. of Boudadi-Maligne et al. (2016) from the site of Pointe Gros Rempart 6 (La Désirade Island). Our observations of ontogenetic variability of Alsophis antillensis and of Erythrolamprus vertebral morphology suggest that small fossil dipsadid vertebrae previously left unidentified can be confidently attributed to $A$. antillensis. 


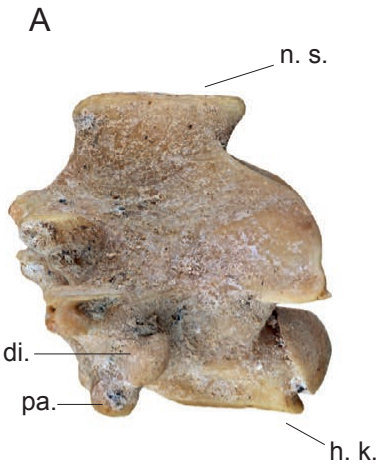

Left lateral view

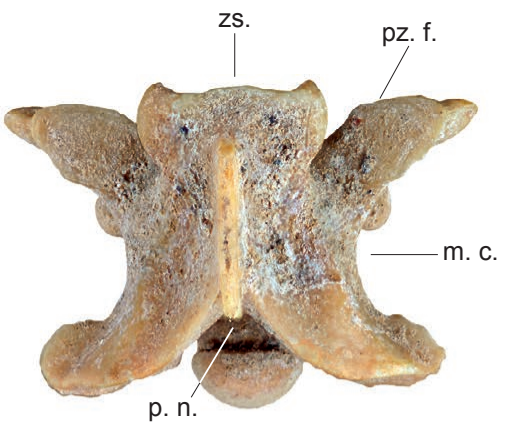

p. $n$

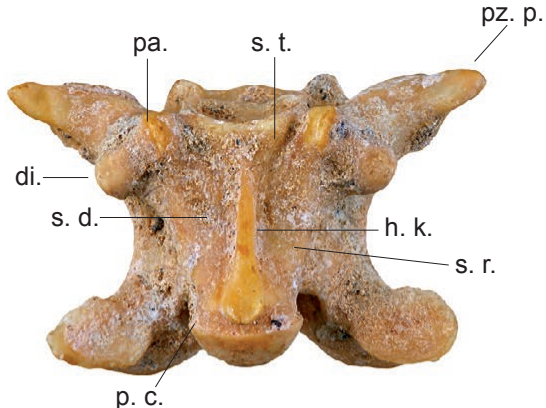

Ventral view

pz. p.

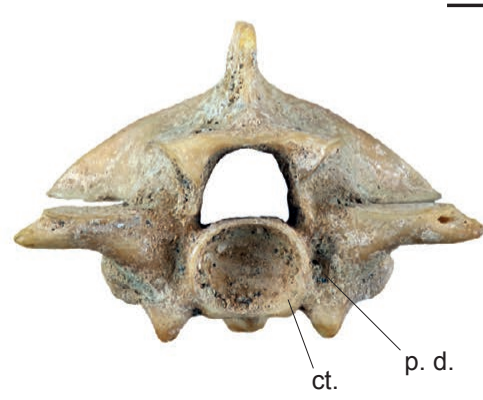

Anterior view

Dorsal view

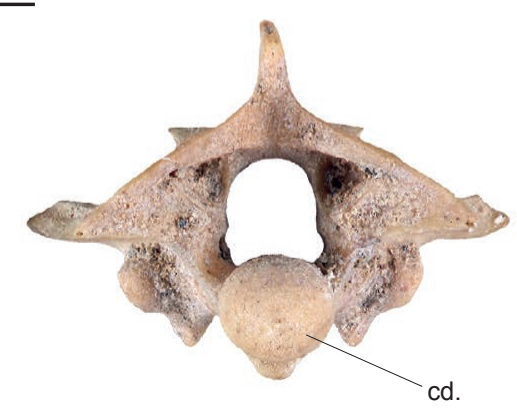

Posterior view

B

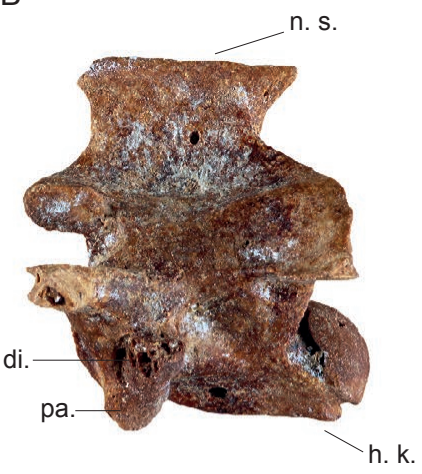

Left lateral view

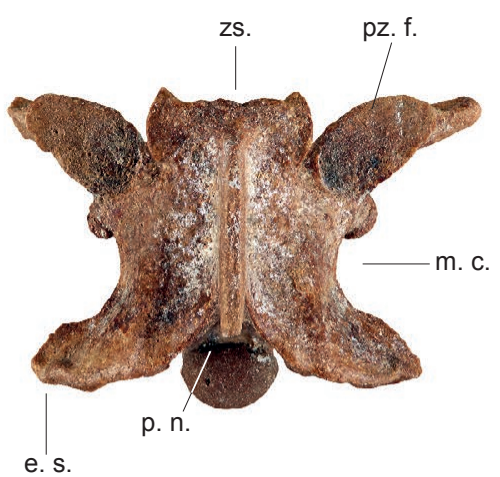

Dorsal view

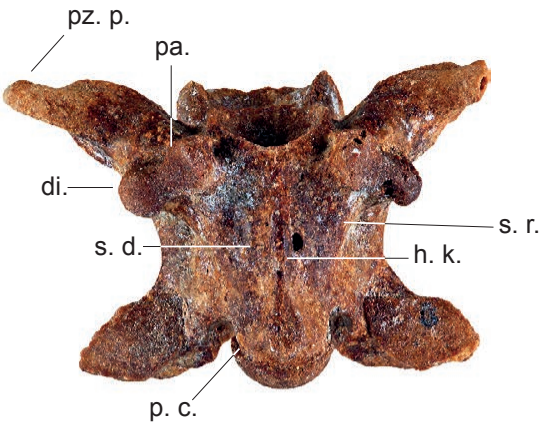

Ventral view

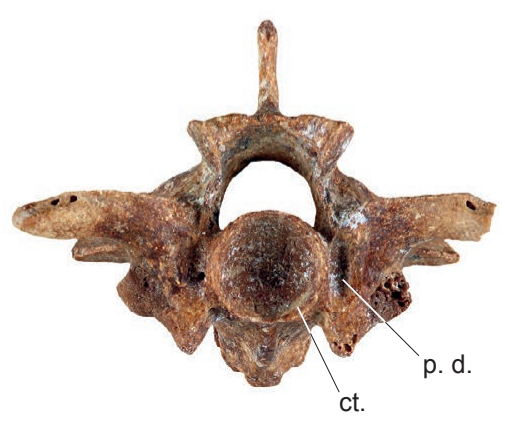

Anterior view

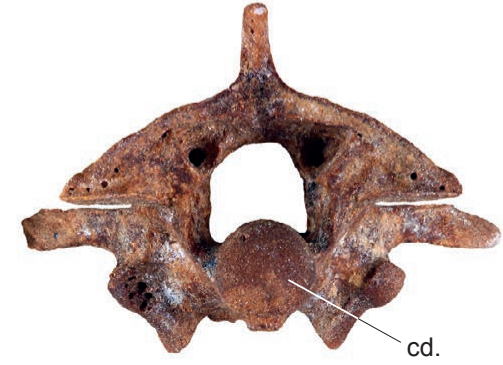

Posterior view

FIG. 5. - Trunk vertebrae of Alsophis antillensis (Schlegel, 1837) from Gare Maritime de Basse-Terre archaeological site (US 1008) located on Basse-Terre Island (A) and from Blanchard Cave paleontological deposit (Layer 11) located on Marie-Galante Island (B). Abbreviations: cd., condyle; ct., cotyle; di., diapophysis; e. s., epizygapophyseal spine; h. k., hemal keel; m. c., medial constriction; n. s., neural spine; p. c., precondylar constriction; p. d., paracotylar depression; p. n., postero-medial notch of the zygantrum; pa., parapophysis; pz. f., prezygapophyseal facet; pz. p., prezygapophyseal process; s. d., subcentral depression; s. r., subcentral ridge; s. t., sub-cotylar tubercle; zs., zygosphene. Scale bars: $4 \mathrm{~mm}$. 


\section{Alsophis sp. 2}

EXAMINED MATERIAL. - A total of 51 bones, all trunk vertebrae, from 11 sites on all islands except Petite-Terre (see Table 1) are attributed to an unknown species of the genus Alsophis.

\section{DESCRIPTION}

Trunk vertebrae (51 elements; Fig. 6A)

These vertebrae are of intermediate size, with centra lengths between 2.7 and $4.4 \mathrm{~mm}$. In dorsal view, their proportions range from short and slightly wider than long to slightly longer than wide $(\mathrm{CL} / \mathrm{WIC}=0.86-1.15)$ and consistently exhibit a strong medial constriction. Still in dorsal view, the zygosphene is wide with a slightly trilobate anterior margin, the prezygapophyseal facets are ovoid, and the prezygapophyseal processes are conical and elongate (1.5 longer than wide) with a blunted distal end. In lateral view, the neural spine is clearly higher than long and has vertical anterior and posterior margins. The hemal keel is more extended ventrally than in fossil trunk vertebrae of $A$. antillensis and has a straight ventral margin becoming shallower anteriorly. The hemal keel does not reach the sub-cotylar ring and it forms a distinct step under the posterior limit of the diapophysis. In ventral view, the hemal keel is laterally well-delimited, thin, and is more or less spatulate in shape (sensu Holman 2000) with a posterior enlargement of variable extent. In anterior view, the cotyle is small, deep, and circular. It is laterally bordered by paracotylar foramina and deep paracotylar depressions. In posterior view, the neural arch is strongly vaulted and thicker than in the other studied fossil dipsadid snakes, and the condyle is small and circular. In ventral view, the centrum is triangular and its anterior part bears well-marked subcentral ridges and deep subcentral grooves.

\section{REMARKS}

These fossil vertebrae exhibits significant differences relative to those attributed to Alsophis antillensis: they are shorter with a stronger medial constriction in dorsal view; the neural spine is higher and shorter in lateral view, with straighter anterior and posterior margins; well-marked subcentral ridges are visible in lateral view; the cotyle is small and circular in anterior view; and the neural arch is thicker and more vaulted in posterior view. We observed all these characteristics in modern Alsophis rufiventris trunk vertebrae, a snake occurring in Saba and possibly extinct in Saint-Christopher banks (Powell \& Henderson 2012), which conservatively indicates that our fossil snake was part of the genus Alsophis. Similar vertebrae were identified as Colubroidea sp. 2 or Dipsadidae sp. 2 in previous studies (Bochaton et al. 2015; Bailon et al. 2015). However, comparative specimens are too scarce for us to confidently attribute these 51 vertebrae to $A$. rufiventris. Instead, we assign these specimens to an unknown and extinct species of Alsophis that was morphologically close to Alsophis rufiventris, a species known to have occurred at least $120 \mathrm{~km}$ north of the Guadeloupe Islands. Fossil vertebrae exhibiting a similarly short centrum and high neural spine were described by Auffenberg (1958) on Barbuda and attributed to the genus Clelia. Unfortunately, Auffenberg (op. cit.) never figured these vertebrae and his material is not available in the collections of the Florida Museum of Natural History. We believe it is likely that the vertebrae described by Auffenberg were similar to the ones we describe here and thus propose his material so that they also can be referred to the genus Alsophis. A gross size comparison with modern Alsophis specimens shows that fossil vertebrae from the Guadeloupe Islands correspond to individuals between 75 and $120 \mathrm{~cm}$ in total length.

\section{Genus Alsophis Fitzinger, 1843}

\section{Alsophis sp.}

EXAMINED MATERIAL. - 1049 bone elements corresponding to broken trunk vertebrae, cervical vertebrae, and post-cloacal vertebrae are attributed to the genus Alsophis on the basis of their size and overall morphology.

\section{REMARKS}

The morphology of cervical and post-cloacal vertebrae was not deeply studied in the framework of this study which precludes a specific identification. These elements were associated to Alsophis mainly on the basis that it was possible to confidently assume they belong to a colubrid snake larger than Erythrolamprus and presenting no strong difference with our modern specimens of Alsophis.

\section{Genus Erythrolamprus Wagler, 1830}

Erythrolamprus juliae cf. copeae (Parker, 1936)

EXAMINED MATERIAL. - Six elements, all trunk vertebrae, collected from Basse-Terre and Grande-Terre islands (see Table 1), are attributed to the species Erythrolamprus juliae cf. copeae.

\section{DESCRIPTION}

Trunk vertebrae (6 elements; Fig. 6B)

These six vertebrae have centra lengths between 2.7 and $3.2 \mathrm{~mm}$. In dorsal view, they are more elongate than the previously described fossil vertebrae and clearly longer than wide (ratio CL/WIC = 1.18-1.35). The prezygapophyseal processes are thick, conical, with blunted apex, and are more anteriorly oriented than in Alsophis fossil morphotypes. Prezygapophyseal facets are ovoid in dorsal outline. The medial constriction is less pronounced than in the previously described vertebrae. The zygosphene is wide, with a slightly lobate anterior margin. The postero-medial notch of the neural arch is less flared than in other fossil vertebrae described here and forms an angle of $45^{\circ}$. There is no epizygapophyseal spine. In lateral view, the neural spine is long and low, approximately 3.5 times longer than high. This structure has a concave anterior margin with a slightly overhanging anterior projection and a vertical posterior margins without any overhang. The interzygapophyseal crest is straight. In the synapophysis, the diapophysis and parapo- 


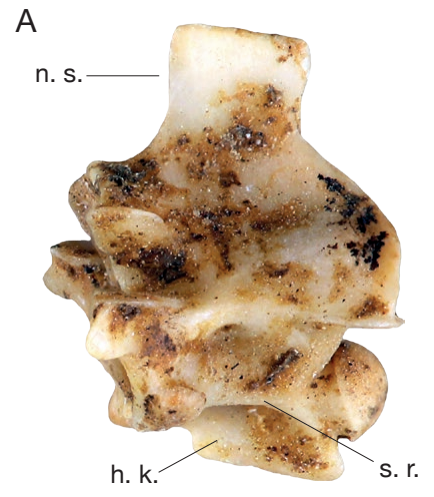

Left lateral view

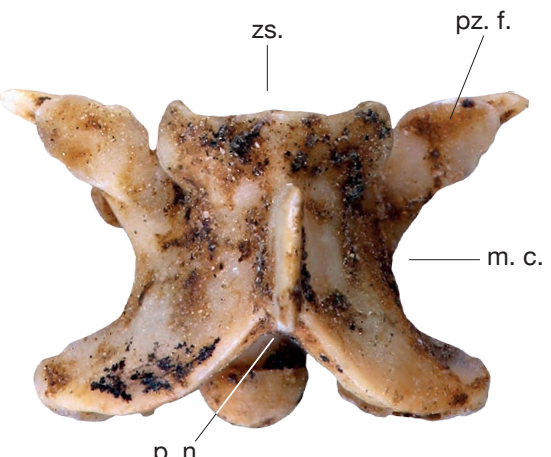

p. n.

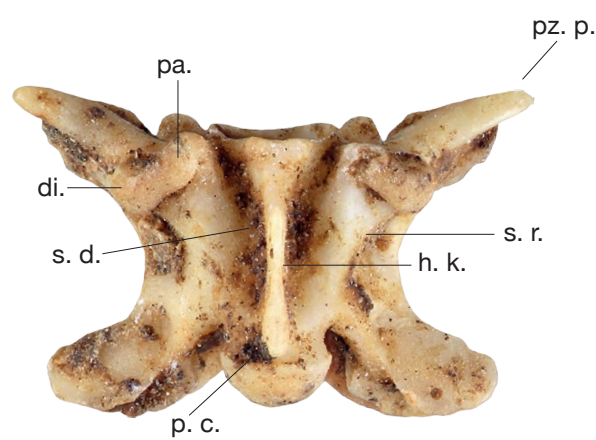

p.c.

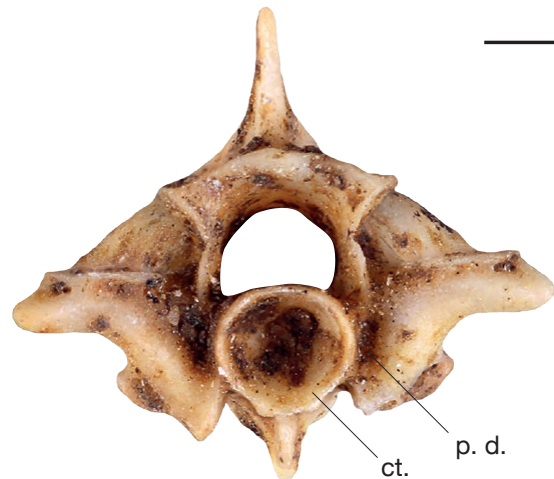

Ventral view

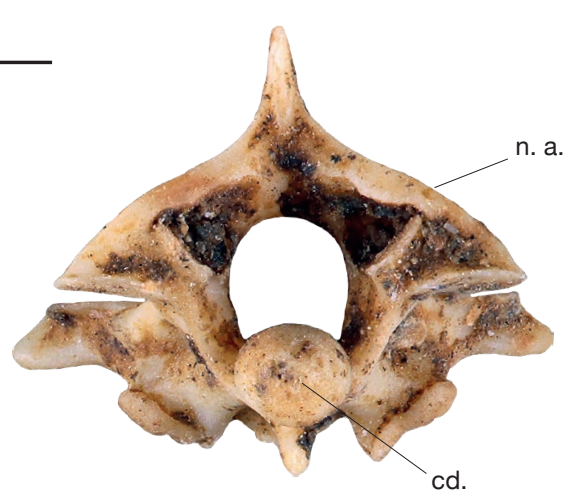

Anterior view

Posterior view

B

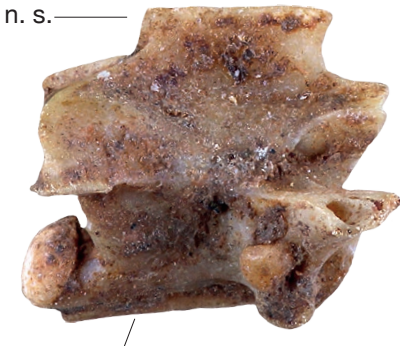

h. k.

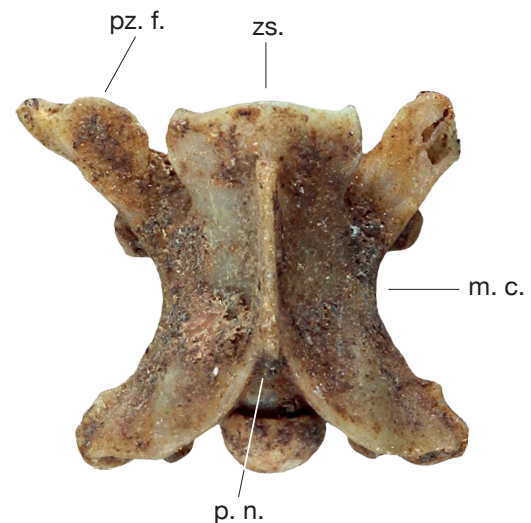

Dorsal view

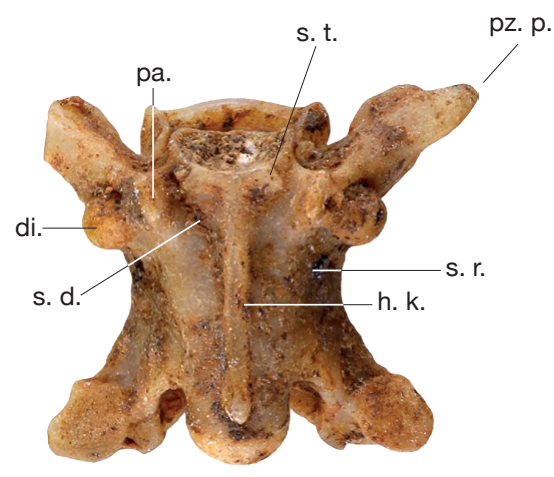

Ventral view
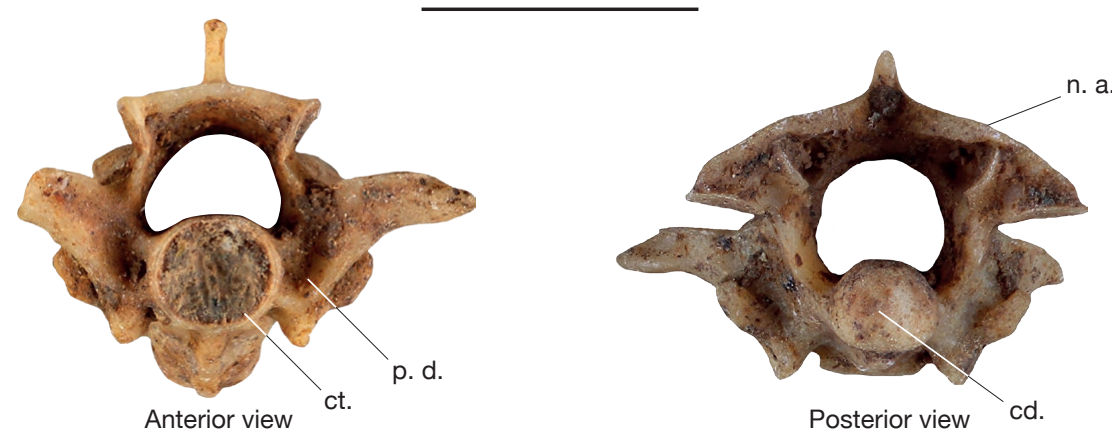

FIG. 6. - A, Trunk vertebra of Alsophis sp. 2 from Pointe du Helleux archaeological site (Square 2 - crab layer) located on Grande-Terre Island; B, trunk vertebra of Erythrolamprus juliae cf. copeae (Parker, 1936) from Sainte-Rose La Ramée archaeological site (US 2058) located on Basse-Terre Island. Abbreviations: cd., condyle; ct., cotyle; di., diapophysis; h. k., hemal keel; m. c., medial constriction; n. a., neural arch; n. s., neural spine; p. c., precondylar constriction; p. d., paracotylar depression; p. n., postero-medial notch of the zygantrum; pa., parapophysis; pz. f., prezygapophyseal facet; pz. p., prezygapophyseal process; s. d., subcentral depression; s. r., subcentral ridge; s. t., sub-cotylar tubercle; zs., zygosphene. Scale bars: $4 \mathrm{~mm}$. 
physis are slightly more separated than in Alsophis morphotypes, but their relative positions are similar. The diapophysis is clearly larger than the parapophysis. Ventrally, a long and shallow hemal keel with a straight ventral edge and a slight posterior projection is visible. In anterior view, the cotyle is circular and it is bordered laterally by paracotylar foramina and deep paracotylar depressions. In posterior view, the condyle is circular and the neural arch is dorsally flattened. The centrum is cylindrical in transverse section. In ventral view, the centrum has weakly marked subcentral ridges and lacks the precondylar constriction occurring in Alsophis fossil vertebrae. The hemal keel is shaped like a gladius shape and its width is constant along its whole length. Two subcentral depressions of shallow depth and limited extent are visible on the anterior part of the centrum below the synapophysis. Sub-cotylar tubercles occur ventral to the cotyle on some specimens.

\section{REMARKS}

These vertebrae present two characters occurring in Erythrolamprus and not in Alsophis: the vertebra is clearly longer than wide and the neural spine is anteroposteriorly elongate and low. These same fossils also exhibit several differences with our two comparative extant specimens of Erythrolamprus perfuscus: lack of a strongly trilobed anterior margin of the zygosphene in dorsal view; cylindrical shape of the centrum with weakly defined lateral margins; lack of precondylar constriction separating the centrum from the condyle; and narrowness of the postero-medial notch in the neural arch forming an angle clearly less than $90^{\circ}$ in dorsal view. All these characters that do not occur in E. perfuscus occur on our unique individual of E. juliae copeae (MNHN-RA-1998.485). Still, some differences exist between this last individual and the fossil vertebrae. Most notably, in our modern individual, the prezygapophyseal processes are wider and shorter and the zygosphene is narrower than in some fossils. In addition, the hemal keel in the modern individual is shorter and its posterior end is enlarged in ventral view, and the cotyle is ovoid in anterior view. Considering the strong morphological affinities between the fossil vertebrae and our modern specimen of $E$. j. copeae and the fact that this sub-species currently occurs on the Guadeloupe Islands, the fossils may belong to that sub-species. However, because comparative specimens of Erythrolamprus juliae are scarce $(\mathrm{n}=5)$ we are unable to determine if the observed morphological differences between fossils and our modern specimens are reliably diagnostic at the sub-species level. We thus conservatively identify these six fossil vertebrae as Erythrolamprus juliae cf. copeae. A gross comparison of the centrum length of fossil vertebrae with modern specimens indicates fossils snakes were about $44-54 \mathrm{~cm}$ in total length, a size similar to the modern individuals of E. j. copeae (see Breuil 2002).

\section{Superfamily Colubroidea Oppel, 1811}

EXAMINED MATERIAL. - 128 bone elements all representing colubridae (sensu lato) fragmented pre-cloacal and post-cloacal vertebrae could not be identified to the genus level.

\section{MORPHOMETRIC ANALYSIS OF MODERN AND FOSSIL VERTEBRAE}

The first analysis was conducted on only four variables (CL, MLV, WIC, and WP) and includes all fossil morphotypes described above ( $n=312$ specimens). The two first axes of the PCA (Fig. 7A) reflect the significant differences occuring between modern Alsophis and Erythrolamprus (Manova, p. val<0.01), which do not exhibit any morphological overlap in the PCA. Fossil Erythrolamprus vertebrae do not significantly differ from modern Erythrolamprus (Manova, p.val>0.01), but they do differ significantly from both fossil (Manova, p. val<0.01) and modern (Manova, p.val<0.01) Alsophis. The morphology of fossil Erythrolamprus seems intermediate between our two modern Erythrolamprus species, but the limited number of available variables and comparative specimens do not allow for a specific attribution for the Erythrolamprus fossils. Still, morphometric data confirm the generic attribution made on the basis of morphological criteria. Concerning Alsophis, this analysis reveals no significant differences between modern $A$. antillensis and $A$. rufiventris (Manova, p.val>0.01); these two species thus are considered together in subsequent analyses. The results reveal significant differences between the two fossil Alsophis morphotypes (Manova, p.val<0.01) and between the modern $A$. antillensis/rijgersmaei and $A$. rufiventris (Manova, p.val<0.01). Fossil $A$. antillensis vertebrae, although being significantly different from modern $A$. rufiventris (Manova, p.val<0.01), not significantly differ from modern $A$. antillensis/rijgersmaei (Manova, p.val>0.01). Our second fossil Alsophis morphotype, however, is significantly different from all modern taxa (Manova, p.val>0.01). The Mahalanobis distance tree constructed on the results of a LDA performed on the axes of the above mentioned PCA (Fig. 7B) confirms the intermediate position of fossil Erythrolamprus between modern E. juliae copeae and E. perfuscus, as well as the morphological similarities between modern and fossil Alsophis.

The second analysis performed on all the variables and limited to Alsophis fossil and modern vertebrae reveals that most of fossil Alsophis antillensis vertebrae fall in the range of variability of modern $A$. antillensis and $A$. rijgersmaei (Fig. 7C). Alsophis antillensis fossil vertebrae do not significantly differ from modern $A$. antillensis and $A$. rijgersmaei considered as a single group (Manova, p.val>0.01), but differ from both modern species taken individually (Manova, p.val<0.01). The position of Alsophis sp. 2 vertebrae on the two first axis of the PCA is intermediate between the three modern Alsophis species included in our study ( $A$. antillensis, $A$. rijgersmaei, and $A$. rufiventris). It slightly overlaps the morphological diversity of fossil Alsophis antillensis and $A$. rufiventris. Manova tests indicate that Alsophis sp. 2 vertebrae significantly differ from all fossil and modern groups (Manova, p.val<0.01). However, the small number of Alsophis sp. 2 specimens available to conduct the statistical tests makes the results difficult to 


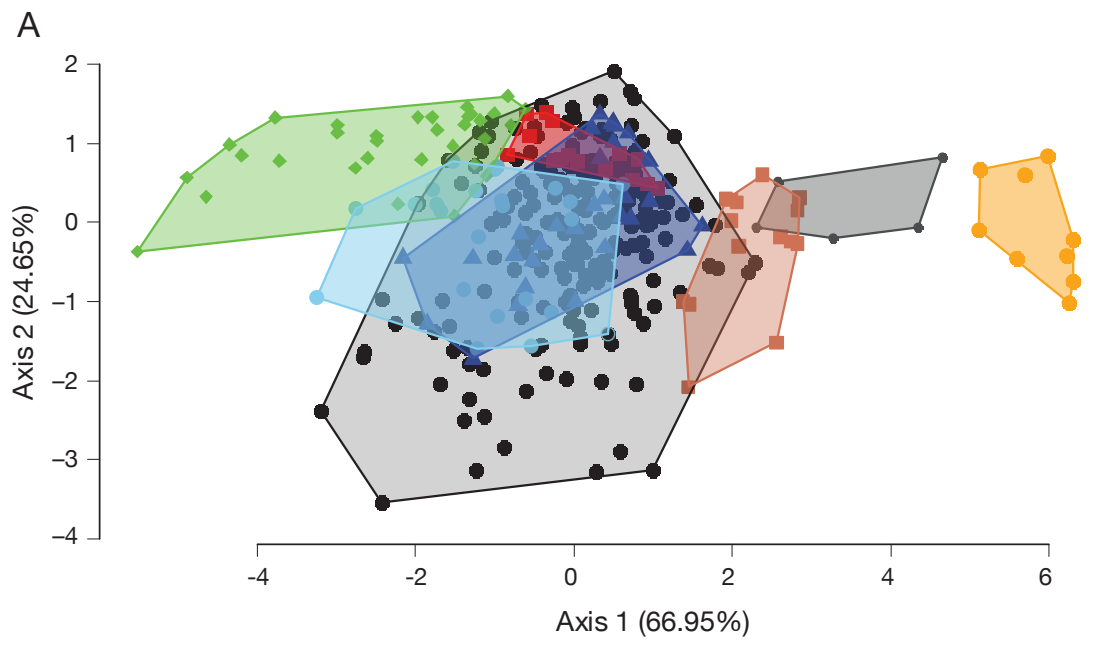

B

1 Modern Alsophis rufiventris

2 Fossil Alsophis sp. 2

3 Modern Alsophis antillensis/rijgersmaei

4 Fossil Alsophis antillensis

5 Erythrolamprus perfuscus

6 Fossil Erythrolamprus juliae cf. copeae

7 Erythrolamprus juliae copeae

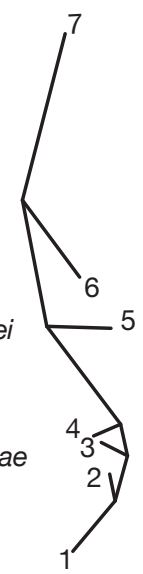

- Fossil Alsophis antillensis (Schlegel, 1837)

^ Modern Alsophis rijgersmaei Cope, 1869

- Modern Erythrolamprus juliae copeae
Fossil Alsophis sp. 2

- Modern Alsophis antillensis
- Fossil Erythrolamprus juliae cf. copeae (Parker, 1936)

- Modern Alsophis rufiventris

Modern Erythrolamprus perfuscus (Cope, 1862)
C

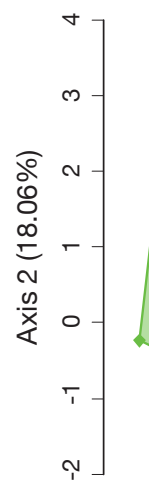$$
-4
$$
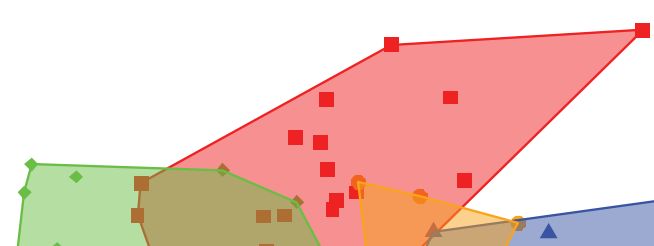

$-1$
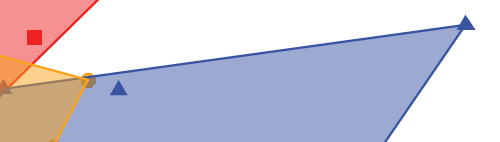

Fossil Alsophis antillensis

Modern Alsophis rijgersmaei
D

1 Modern Alsophis rufiventris

2 Fossil Alsophis sp. 2

3 Modern Alsophis antillensis

4 Fossil Alsophis antillensis

5 Modern Alsophis rijgersmaei

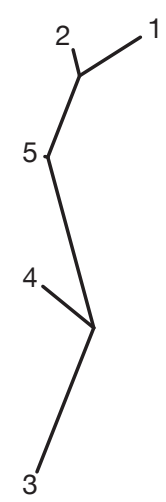

FIG. 7. - Results of statistical analyses of fossil and modern dipsadid snake vertebrae on the Guadeloupe Islands: A, two first axes of the PCA conducted on the maximum number of specimens (first analysis); B. Mahalanobis distance tree obtained from the results of the LDA (first analysis); $\mathbf{C}$, two first axes of the PCA conducted on the maximum number of measurements (second analysis); D, Mahalanobis distance tree obtained from the results of the LDA (second analysis).

interpret. The Mahalanobis distance tree (Fig. 7D) further confirms the morphological similarities between modern A. rufiventris and fossil Alsophis sp. 2, which are closer to each other than with other species of the sample. In the same analysis, fossil Alsophis antillensis is as distant from A. rufiventris as from $A$. rijgersmaei. This distance is similar to that between Alsophis sp. 2 and A. rufiventris.

Our two morphometric analyses confirm the results of the morphological observations, but fail to provide further resolution for the taxonomic affinities of the fossil vertebrae. This likely was due to the small number of available modern specimens, which fail to capture the full morphological variability within each taxon.
Concerning only fossil $A$. antillensis vertebrae, the analysis conducted on four variables indicates significant differences (Manova, p.val<0.01) between vertebrae collected on the different Guadeloupe Islands, but these differences are no longer significant if the analysis is conducted on eight variables (Manova, p.val>0.01). Considering the small number of available specimens in the eight variables analysis and the possible bias impacting the analysis conducted on four variables we are unable to state whether the observed differences represent true morphological differences that reflect taxonomic differences. The analysis of four variables also indicates no differences between vertebrae collected in Pleistocene and Holocene layers on Marie-Galante Island 
A

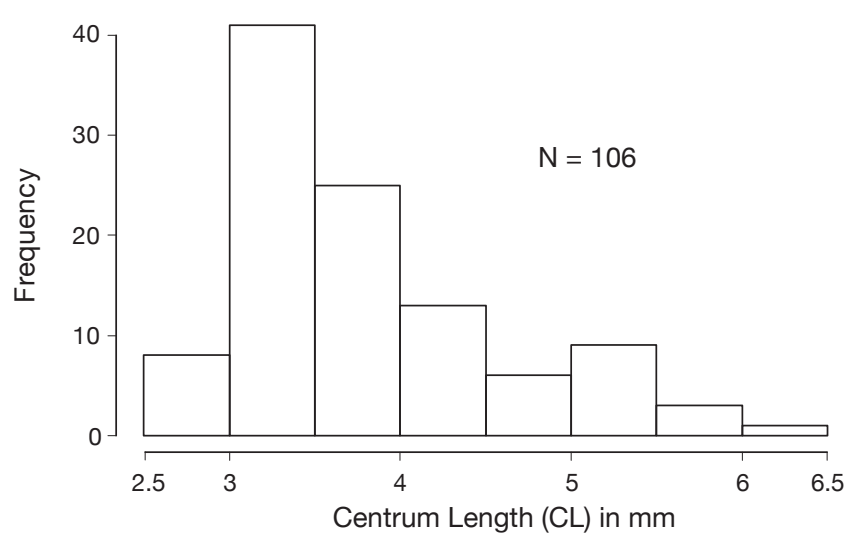

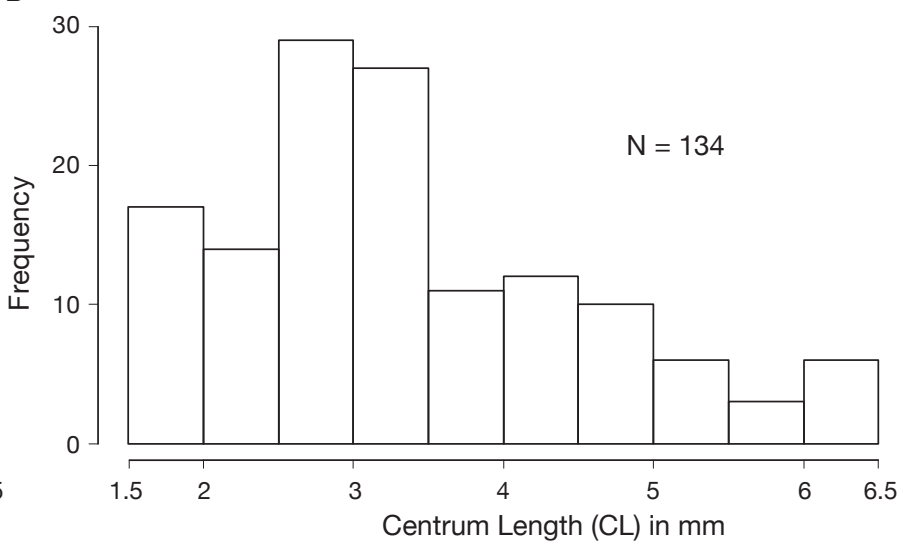

FIG. 8. - Distribution of size (centrum length) of snake vertebrae from archaeological deposits (A) and natural deposits (B) on the Guadeloupe Islands.

(Manova, p.val>0.01); however, the samples are too small to test potential morphological difference between vertebrae collected in archaeological and natural deposits.

\section{ZOOARCHAEOLOGICAL ANALYSIS}

The 438 snake bones recovered from archaeological deposits (Table 1) are mostly vertebrae. With the exception of the Grande-Anse de Terre-de-Bas site, the number of specimens collected from each archaeological site does not exceed 72 and is below 50 for most of them (Table 1). Considering the number of vertebrae occurring in a complete Alsophis antillensis specimen (more than 280 - pers. obs.), the minimal number of individuals (MNI) of each site never exceeds one, making occurrences of snake fossils, although nearly ubiquitous, a minor component in archaeological sites. Among vertebrae collected from archaeological deposits, only four sites (Anse Petite-Rivière, Sainte-Rose La Ramée, Anse à la Gourde, and Tourlourous) yielded specimens exhibiting burning traces. No cut marks were observed on any specimens included in our study.

The size distribution of vertebrae (centrum length) in archaeological sites (Fig. 8A) is partly similar to that in natural deposits (Fig. 8B), although it is significantly different (t. test, p.val<0.01). The main difference concerns the lack of specimens less than $3 \mathrm{~mm}$ long in archaeological sites. This clearly reflects a recovery bias, because mesh size used to recover small bones are mostly $2.7 \mathrm{~mm}^{2}$ for archaeological deposits versus $2 \mathrm{~mm}^{2}$ or less for natural deposits. Aside from that difference, both types of sites have a good representation of vertebrae between 3 and $4 \mathrm{~mm}$ long and a decreasing proportion of vertebrae between 4 and $6.5 \mathrm{~mm}$ long. This similarity is confirmed by the t. test, which demonstrates that size distributions at both types of site is no longer significantly different if specimens below $3 \mathrm{~mm}$ are removed (t. test, p.val $>0.01)$. Both kinds of sites tend to lack vertebrae from large-sized snakes. This bias could be explained in natural deposits where raptors, possibly being the accumulator agents, may avoid the largest snakes. In archaeological deposits, the absence of large specimens could indicate mutual avoidance between large snakes and humans.

\section{DISCUSSION}

PAST GUADELOUPE DIPSADID SNAKE DIVERSITY Morphological and morphometric evidences demonstrate the occurrence of three distinct dipsadid snake fossil morphotypes on the Guadeloupe Islands. The first morphotype corresponds to Alsophis antillensis, an endemic snake of the Guadeloupe Islands currently occurring on Basse-Terre and Grande-Terre islands. Fossil evidence demonstrates this species occurred on all islands of the Guadeloupe archipelago in the past (Fig. 9), at least during Amerindian occupation. Fossil data supports the historical writings of Jean-Baptiste Du Tertre $(1654,1667)$, who stated this snake occurred on all Guadeloupe islands in the $17^{\text {th }}$ century. However, the maximum size of our fossils (around $150 \mathrm{~cm}$ of total length) is clearly lower than the maximum size described by $\mathrm{Du}$ Tertre $(190 \mathrm{~cm})$. This is raises questions about how representative the fossil assemblages are, if larger specimens may be excluded from the fossil record. We also attribute the fossil vertebrae collected on Les Saintes Islets to $A$. antillensis. However, although we did not observe differences between fossils vertebrae collected on Les Saintes and other Guadeloupe islands, the vertebral morphology of the species occurring nowadays in Les Saintes islands, A. sanctonum, remains unknown. This raises the possibility that at least some specimens from Les Saintes may pertain to $A$. sanctonum.

The second fossil morphotype corresponds to a member of the genus Erythrolamprus (E. juliae cf. copeae). This morphotype is far scarcer in the fossil assemblages and only occurs on Basse-Terre and Grande-Terre Islands in Amerindian deposits (Fig. 9). This constitutes the first fossil report of this genus in the archipelago. Nowadays, E. juliae occurs in Basse-Terre and Grande-Terre islands, but is absent from all others islands (Powell \& Henderson 2012), with the exception of Marie-Galante where it is reported as having gone extinct (Henderson 1992; Breuil 2002). This snake also was probably mentioned by Du Tertre (1667) who signaled its occurrence on all Guadeloupe islands. The scarcity of this snake in fossil deposits possibly 


\begin{tabular}{|c|c|c|c|c|}
\hline Les Saintes & Late Pleistocene & Pre-anthropic Holocene & Amerindian periods & Nowadays \\
\hline Alsophis antillensis and sanctonum & \multicolumn{2}{|r|}{ No Data } & Present & Present \\
\hline Alsophis sp. 2 & \multicolumn{2}{|r|}{ No Data } & Present & Absent \\
\hline Erythrolamprus juliae ssp. & \multicolumn{2}{|r|}{ No Data } & Absent & Absent \\
\hline \multicolumn{5}{|l|}{ Grande-Terre } \\
\hline Alsophis antillensis & \multicolumn{2}{|r|}{ No Data } & Present & Present \\
\hline Alsophis sp. 2 & \multicolumn{2}{|r|}{ No Data } & Present & Absent \\
\hline Erythrolamprus juliae cf. copeae & \multicolumn{2}{|r|}{ No Data } & Present & Present \\
\hline \multicolumn{5}{|l|}{ Basse-Terre } \\
\hline Alsophis antillensis & \multicolumn{2}{|r|}{ No Data } & Present & Present \\
\hline Alsophis sp. 2 & \multicolumn{2}{|r|}{ No Data } & Present & Absent \\
\hline Erythrolamprus juliae cf. copeae & \multicolumn{2}{|r|}{ No Data } & Present & Present \\
\hline \multicolumn{5}{|l|}{ La Désirade } \\
\hline Alsophis antillensis & \multicolumn{2}{|r|}{ No Data } & Present & Absent \\
\hline Alsophis sp. 2 & \multicolumn{2}{|r|}{ No Data } & Present & Absent \\
\hline Erythrolamprus juliae ssp. & \multicolumn{2}{|r|}{ No Data } & Absent & Absent \\
\hline \multicolumn{5}{|l|}{ Petite-Terre } \\
\hline Alsophis antillensis & \multicolumn{2}{|r|}{ No Data } & Present & Absent \\
\hline Alsophis sp. 2 & \multicolumn{2}{|r|}{ No Data } & Absent & Absent \\
\hline Erythrolamprus juliae ssp. & \multicolumn{2}{|r|}{ No Data } & Absent & Absent \\
\hline \multicolumn{5}{|l|}{ Marie-Galante } \\
\hline Alsophis antillensis & Present & Present & Present & Absent \\
\hline Alsophis sp. 2 & Present & Present & Present & Absent \\
\hline Erythrolamprus juliae ssp. & Absent & Absent & Absent & Absent \\
\hline
\end{tabular}

FIG. 9. - Fossil and modern occurrences of the three dipsadid species identified on the Guadeloupe Islands at the different chronological intervals.

provides a distorted image of its past distribution in Guadeloupe. However, the absence of Erythrolamprus in the Marie-Galante fossil record is difficult to explain considering the large numbers of snake vertebrae discovered in the rich fossil bearing deposits on this island. The only physical evidence for the past occurrence of Erythrolamprus on Marie-Galante Island are old museum specimens collected in 1886 prior to the putative extinction of the genus on this island, which occurred around 1880 following Henderson (1992) or later, as hypothesized by Breuil (2002). Fossil and archaeological data however do not confirm the past occurrence of this snake on Marie-Galante.

The third fossil dipsadid snake corresponds to an unidentified member of the genus Alsophis, which occurred in the past on all Guadeloupe islands. This small fossil snake shares morphological similarities with A. rufiventris, but has proved impossible to identify at species level due to the lack of data regarding the osteology of modern Alsophis. Only two species of Alsophis, A. antillensis and A. sanctonum, are known to have occurred on the Guadeloupe Islands and these fossil elements are the first evidence for the past occurrence of another species that is nowadays extinct. Interestingly, this snake does not correspond to the third enigmatic black snake described by Du Tertre $(1654,1667)$ that is reported to reach around seven feet $(224 \mathrm{~cm})$ in total length, making it far larger than our fossil Alsophis sp. 2 (max. $120 \mathrm{~cm}$ in total length). Should the snake described by Du Tertre really have existed in the past, it is possible than four species of dipsadid snakes occurred in the Guadeloupe Islands.
ARE PALEONTOlOGICAL AND ARCHAEOlOGICAL DEPOSITS AN ACCURATE TOOL TO APPRECIATE PAST GUADELOUPE SNAKE BIODIVERSITY?

Snakes remains are often found in archaeological deposits. In our opinion, there is no clear evidence for any selection and consumption of these animals by Amerindians populations for the following reasons: 1) lack of large specimens; 2) similar size distributions of snakes in both archaeological and natural deposits; 3) scarcity of burning traces; and 4) total absence of butchering marks. At least one historical account supports this idea. The Anonymous of Carpentras (1618), who described the daily life of Lesser Antillean Amerindians from Dominica and la Martinique at the beginning of the $17^{\text {th }}$ century, stated that Amerindians "do not catch nor consumed eels because they are sisters of snakes" (Anonymous of Carpentras 1618: 146, translated from French). This could be interpreted as a culinary taboo or fear related to snakes and snake-like animals such as eels. The low occurrence of snake bones in archaeological deposits might be explained by these animals opportunistically feeding on insects and small lizards, which are known to be part of their diet (Henderson \& Bourgeois 1993; Henderson \& Sajdak 1996), attracted by food waste left by Amerindians in the vicinity of their villages. The fact that snakes were not hunted and consumed by Amerindians could explain that large snakes, if any was present in Guadeloupe as suggested by Du Tertre (1667), were not discovered in archaeological sites. Probably also because they were more exposed to be killed by humans if found near their settlement places, compared to their more harmless smaller congeners. Regardless of the reason(s) why 
large-sized snakes are underrepresented in archaeological sites, it is evident that archaeological assemblages incompletely document past biodiversity. Currently available fossil material is thus unsuitable to discard the possible past occurrence of more snakes than those we observed in the deposits. The image of the snake past diversity that we provided should thus be considered a minimum estimation of what it could have been during the last millennia.

Following from the above, a report of a non-xenodontine snakes in the region observe commentary. The genus Clelia Fitzinger, 1826, for which the hypothesis of it having occurred in Guadeloupe is only based on the historical description of the large black snake by Du Tertre (see Breuil 2002). Clelia currently only occurs on the southern Islands of Grenada and Sainte-Lucia (Henderson \& Powell 2009) and there is no fossil evidence of its occurrence in Guadeloupe. Citations in the $\mathrm{PhD}$ work of Grouard (2001b) mentioned the occurrence of fossil Clelia in Guadeloupe, but specimens of this snake were never identified or mentioned by Grouard. The sole report of Clelia in the Lesser Antilles based on a fossil was a vertebra described by Auffenberg (1958) from Barbuda. As mentioned in our account for Alsophis sp. 2 this specimen is lost and likely pertains instead to Alsophis. The last argument for the occurrence of Clelia in Guadeloupe concerns a museum specimen of the continental species Clelia clelia (MNHN-RA-0.169) indicated as originating from Guadeloupe, but for which provenance was considered as "undoubtedly erroneous" by Underwood (1993). In summary, there is no compelling evidence for Clelia in Guadeloupe.

\section{EVOLUTION OF GUADELOUPE DIPSADID SNAKE \\ BIODIVERSITY THROUGH TIME}

Our results provide new insight regarding the evolution of snake biodiversity on the Guadeloupe Islands through time. Concerning, the putative effect of the Pleistocene/Holocene transition on snake biodiversity can only be assessed for Marie-Galante Island, because that is the sole island for which a Pleistocene and early Holocene fossil record is available. Based on our reidentification of Colubroidea sp. 2 of Bochaton et al. (2015), and of Colubridae sp. 2 of Bailon et al. (2015) as Alsophis sp. 2, we can exclude those earlier identified taxa as having gone extinct. Here we report examples of (Alsophis sp. 2) in one of the Marie-Galante pre-Columbian archaeological deposit (Tourlourous/Stade José Bade). Based on current evidence and identifications, the sole squamate extinction occurring at the end of the Pleistocene on Marie-Galante seems to be that of Boa blanchardensis (see Bochaton \& Bailon 2018). During pre-Columbian times, we demonstrate the occurrence of at least three dipsadid taxa on the Guadeloupe Islands (Fig. 9): Alsophis antillensis (on all six islands), Alsophis sp. 2 (on five islands), and Erythrolamprus juliae cf. copeae (on at least two islands) (Fig. 9). Fossil and archaeological data combined with current snake biodiversity in Guadeloupe provide evidence for several extirpations and extinctions during modern times. Alsophis antillensis/sanctonum nowadays only occurs on BasseTerre, Grande-Terre, and Les Saintes islands, although historically having been present also on La Désirade, Petite-Terre, and Marie-Galante Islands (Fig. 9). Nowadays, Erythrolamprus juliae only occurs on Basse-Terre and Grande-Terre Islands, from where fossils of this species were discovered (Table 1; Fig. 9). However, this species possibly underwent extirpation on Marie-Galante islands (Barbour 1914; Henderson 1992; Breuil 2002) although we did not identify any fossils on this island. This taxon is scarce in fossil deposits and there is a possibility that past populations may have existed on La Désirade, Petite-Terre, and Les Saintes islands, although this currently lacks any fossil evidence. Our Alsophis sp. 2 occurred on nearly all islands during pre-Columbian times, but is no longer present in Guadeloupe (Fig. 9). In summary, dipsadid snakes underwent at least one extinction (Alsophis sp. 2), at least three extirpations of Alsophis antillensis, and one extirpation of Erythrolamprus juliae during modern time. The obtained global extinction/extirpation rate for dipsadid snake species occurring in Guadeloupe before the $17^{\text {th }}$ century is $61 \%$. This rate may be even higher $(70 \%)$ if past dipsadid snakes described in historical reports, but not yet confirmed by fossil remains, are included. The global extinction rate of snakes during the Holocene is slightly impacted by adding non-dipsadid Guadeloupe snake taxa. Fossil typhlopid snakes remains were discovered on Basse-Terre, Grande-Terre and Marie-Galante Islands (CB pers. obs.; Bochaton et al. 2015; Bailon et al. 2015) but this taxon is only nowadays extinct on the last island (Powell \& Henderson 2012; Breuil 2002). Considering boid snakes, although fossils of Boa were discovered in Pleistocene layers on Marie-Galante Island, there remains no strong evidence of the occurrence of a native Boa during Holocene on the Guadeloupe islands. Consequently the minimal global extinction/extirpation rate for snakes during the Holocene on the Guadeloupe Islands would be of $56 \%$. This rate is similar to the one observed for lizards on MarieGalante Island (57\%, see Bailon et al. 2015). Extinction rates of squamates on Marie-Galante Island are difficult to compare to other Lesser Antillean islands, because the later often lack informative fossil records. Still, a comparison can be made with the squamates of Antigua and Barbuda Islands, which are well documented from a paleontological point of view (Etheridge 1964; Steadman et al. 1984; Pregill et al. 1988). Paleontological and modern data indicated squamate extinction rates of $40 \%$ for Antigua and Barbuda but, higher rates of $66 \%$ (four of six species) for snakes (Etheridge 1964; Steadman et al. 1984; Pregill et al. 1988; Powell \& Henderson 2012). The similar results observed on these islands demonstrate the strong impact of anthropic phenomenon on snakes during the last centuries. This strong extinction rate of snakes could have several explanations including systematic hunting by Man, predation by exogenous mammalian predators, destruction of their habitats, or a combination of those factors. The strong extinction rate of squamates, however, is not surprising considering the numerous extinction events also recorded for other West Indian taxa such as mammals (litt. rev. in Cooke et al. 2017) and birds (see e.g. Steadman et al. 2015).

Our results demonstrate how fossil data can help evaluate the extinction rates of insular snake faunas in response to anthropic modifications and reveal the vulnerability of 
snakes to extinction phenomenon. Human impact on snake biodiversity in the Lesser Antilles is most likely still largely underestimated considering the lack of fossil data on most islands and the gap in the distribution of some taxa (e.g. Boa) across islands. Another difficulty concerns the specific identification of fossil snakes, which is made more complex by the lack of comparative specimens (Bell \& Mead 2014) although it is possible using the appropriate reference sample (see e.g. Mead \& Steadman 2017). Consequently, it is likely that several other now extinct fossil snakes still wait to be discovered and described in the Lesser Antilles. However, this can only be done by conducting fieldwork on the numerous islands lacking a fossil record and by devoting much more attention to the exhaustively documenting the osteological morphology of modern taxa.

\section{Acknowledgements}

The authors are extremely grateful to James Gardner who reviewed and provided several comments regarding this study along with an extensive revision of the English of this paper. We are also grateful to Marc Augé who evaluated this work and provided several comments helping us to improve this study. We sincerely thank the Museum of Comparative Zoology (J. Rosado), and the Muséum national d'Histoire naturelle (N. Vidal) for the loan of museum specimens. We thank C. Sheehy for allowing us the access to the collections of the Florida Museum of Natural History. We are also grateful to the team of CeMIM (USM 0504, Department RDDM, MNHN) for access to their three-dimensional workstation. X-ray CT at the University of Poitiers, which was supported by grants from the Poitou-Charentes Région (16-17-79-86). We also wish to thank all the excavation directors of the studied sites: P. Bodu, D. Bonnissent, M. Boudadi-Maligne, F. Casagrande, A. Chancerel, E. Clerc, C. Colas, P. Courtaud, A. Delpuech, P. Fouéré, J. Gagnepain, C. Hofman, M. Hoogland, A. Lenoble, M.-A. Paulet-Locart, T. Romon, N. Sellier-Segard, N. Serrand, C. Stouvenot, and M. de Waal. The main contributor of this work (CB) is funded by a fellowship granted by the FYSSEN foundation.

\section{REFERENCES}

AlBino A. M. 2011. - Morfología vertebral de Boa constrictor (Serpentes: Boidae) y la validez del género mioceno Pseudoepicrates Auffenberg, 1923. Ameghiniana 48 (1): 53-62. https://doi. org/10.5710/AMGH.v48i1(302)

ANONYMOUS OF CARPENTRAS 1618. - Relation d'un Voyage infortuné fait aux Indes Occidentales par le Capitaine Fleury avec la Description de quelques Isles qu'on y rencontre, par l'un de ceux de la Compagnie qui fit le Voyage, in MOREAU J. P. (ed.), Un flibustier français dans la mer des Antilles 1618-1620. Petite bibliothèque Payot, Paris, 328 p. https:/gallica.bnf.fr/ark:/12148/btv1b53184366n

AUFFENBERG W. 1958. - A small fossil herpetofauna from Barbuda, Leeward Islands, with the description of a new species of Hyla. Quarterly Journal of the Florida Academy of Science 21: 248-254. http://www.biodiversitylibrary.org/page/41494603

Bailon S., Bochaton C. \& Lenoble A. 2015. - New data on Pleistocene and Holocene herpetofauna of Marie-Galante
(Blanchard Cave, Guadeloupe Islands, French West Indies): Insular faunal turnover and human impact. Quaternary Science Reviews 128: 127-137. https://doi.org/10.1016/j.quascirev.2015.09.023

BARBOUR T. 1915. - Recent notes regarding West Indian reptiles and amphibians. Proceedings of the Biological Society of Washington 28: 71-78. http://www.biodiversitylibrary.org/page/3338480

BARBOUR T. 1914. - A Contribution to the Zooggeography of the West Indies, with Especial Reference to Amphibians and Reptiles. Harvard Universitary Press, Cambridge, 174 p. https://doi.org/10.5962/ bhl.title.49187

Barnosky A. D., Matzke N., Tomiya S., Wogan G. O. U., Swartz B., Quental T. B., Marshall C., MCGuire J. L., LindSEY E. L., Maguire K. C., Mersey B. \& Ferrer E. A. 2011. - Has the Earth's sixth mass extinction already arrived? Nature 471 (7336): 51-57. https://doi.org/10.1038/nature09678

Beets C. J., Troelstra S. R., Grootes P. M., Nadeau M.-J., Borg K. VAN DER, JONG A. F. M. DE, HOFMAN C. L. \& HOOgLAND M. L. P. 2006. - Climate and pre-Columbian settlement at Anse à la Gourde, Guadeloupe, Northeastern Caribbean. Geoarchaeology 21 (3): 271-280. https://doi.org/10.1002/gea.20096

BELL C. J. \& MEAD J. I. 2014. - Not enough skeletons in the closet: collections-based anatomical research in an age of conservation conscience. The Anatomical Record 297 (3): 344-348. https:// doi.org/10.1002/ar.22852

Bérard B. 2013. - The Saladoid, in KeEgan W. F., Hofman C. L. \& Ramos R. R. (eds), The Oxford Handbook of Caribbean Archaeology. Oxford University Press, Oxford: 184-197. https://doi. org/10.1093/oxfordhb/9780195392302.013.0065

Bochaton C. \& Bailon S. 2018. - A new fossil species of Boa Linnaeus, 1758 (Squamata, Boidae) from the Pleistocene of MarieGalante Island (French West Indies). Journal of Vertebrate Paleontology 38 (3). https://doi.org/10.1080/02724634.2018.1462829

Bochaton C., Grouard S., Cornette R., Ineich I., Tresset A. \& BAILON S. 2015. - Fossil and subfossil herpetofauna from Cadet 2 Cave (Marie-Galante, Guadeloupe Islands, F. W. I.): Evolution of an insular herpetofauna since the Late Pleistocene. Comptes Rendus Palévol 14 (2): 101-110. https://doi.org/10.1016/j.crpv.2014.10.005

Bochaton C., Bailon S., Ineich I., Breuil M., Tresset A. \& GROUARD S. 2016a. - From a thriving past to an uncertain future: Zooarchaeological evidence of two millennia of human impact on a large emblematic lizard (Iguana delicatissima) on the Guadeloupe Islands (French West Indies). Quaternary Science Reviews 150: 172-183. https://doi.org/10.1016/j.quascirev.2016.08.017

Bochaton C., Boistel R., Cassagrande F., Grouard S. \& Bailon S. 2016b. - A fossil Diploglossus (Squamata, Anguidae) lizard from Basse-Terre and Grande-Terre islands (Guadeloupe, French West-Indies). Scientific Report 28475 (6): 1-12. https:// doi.org/10.1038/srep28475

Bochaton C., Bailon S., Herrel A., Grouard S., Ineich I., TRESSET A. \& CornetTe R. 2017. - Human impacts reduce morphological diversity in an insular species of lizard. Proceedings of the Royal Society B: Biological Sciences 284 (1857): 20170921. https://doi.org/10.1098/rspb.2017.0921

Bochaton C., Boistel R., Grouard S., Ineich I., Tresset A. \& BAILON S. 2019. - Evolution, diversity and interactions with past human populations of recently extinct Pholidoscelis lizards (Squamata: Teiidae) from the Guadeloupe Islands (French WestIndies). Historical Biology 31 (2): 140-146. https://doi.org/10.1 080/08912963.2017.1343824

BoDU P. 1984. - Rapport sur les deux ateliers de débitage en Désirade. Conseil Général Guadeloupe, Basse-Terre (Guadeloupe).

Bodu P. 1985. - Rapport de fouille "les Sables ", Beauséjour, la Désirade. Conseil Général Guadeloupe, Basse-Terre (Guadeloupe).

Boistel R., Herrel A., Lebrun R., Daghfous G., Tafforeau P., Losos J. B. \& VANHoOYDONCK B. 2011. - Shake rattle and roll: the bony labyrinth and aerial descent in squamates. Integrative and Comparative Biology 56 (4): 957-968. https:// doi.org/10.1093/icb/icr034 
BOnAPARTE C. L. 1838. - Synopsis vertebratorum systematis. Amphibiorum Tabula Analytica. Nuovi Annali delle Scienze Naturali 1: 391-397. https://biodiversitylibrary.org/page/9326555

BONNISSENT D. 2008. - Archéologie précolombienne de l'île de Saint-Martin, Petites Antilles (3300 BP-1600 AD). Université Aix-Marseille, Aix-Marseille, 617 p. https://tel.archives-ouvertes. fr/tel-00403026

Bonnissent D. \& Romon T. 2004. - Fouille de la Cathédrale de Basse-Terre. INRAP, Service régional de l'archéologie de Guadeloupe, Basse-Terre, $51 \mathrm{p}$.

Boudadi-Maligne M., Bailon S., Bochaton C., Cassagrande F., Grouard S., Serrand N. \& Lenoble A. 2016. - Evidence for historical human-induced extinctions of vertebrate species on La Désirade (French West Indies). Quaternary Research 85 (1): 54-65. https://doi.org/10.1016/j.yqres.2015.11.001

BReuil M. 2002. - Histoire naturelle des Amphibiens et Reptiles terrestres de l'archipel Guadeloupéen: Guadeloupe, Saint-Martin, Saint-Barthélémy. Muséum national d'Histoire naturelle, Paris, 348 p. (Patrimoines naturels; 54).

Breuil M., Guiougou F., Questel K. \& Ibéné B. 2009. Modifications du peuplement herpétologique dans les Antilles françaises, disparitions et espèces allochtones $2^{\mathrm{ème}}$ partie: reptiles. Le Courrier de la Nature 251: 36-43.

Casagrande F., Hildebrand M., Serrand N. \& Grouard $S$. 2010. - Sainte Rose la Ramée, in Bilan Scientifique Guadeloupe 2007. Ministère de la culture, Direction du patrimoine, Sousdirection de l'archéologie, Paris: 85-90.

Case T., Bolger D. \& Richman A. 1992. - Reptilian Extinctions: The Last Ten Thousand Years, in FiedLeR P. \& JAIN S. (eds), Conservation Biology. Springer, Boston: 91-125. https:// doi.org/10.1007/978-1-4684-6426-9_5

Ceballos G., Ehrlich P. R., Barnosky A. D., García A., Pringle R. M. \& PALMER T. M. 2015. - Accelerated modern human-induced species losses: entering the sixth mass extinction. Science Advances 1 (5): e1400253. https://doi.org/10.1126/sciadv.1400253

ClerC E. 1964. - Le peuplement précolombien des Antilles et ses vestiges en Guadeloupe. Bulletin de la Société d'Histoire de la Guadeloupe 2: 18-32. https://doi.org/10.7202/1044237ar

Colas C., Bertran P., Chancerel A., Chancerel G. \& RichARD J.-M. 2002. - Le Tourlourous. INRAP, Service régional de l'archéologie de Guadeloupe, Marie-Galante.

Cooke S. B., Dávalos L. M., Mrchajliw A. M., Turvey S. T. \& Upham N. S. 2017. - Anthropogenic extinction dominates Holocene declines of West Indian mammals. Annual Review of Ecology, Evolution, and Systematics 48 (1): 301-327. https://doi. org/10.1146/annurev-ecolsys-110316-022754

COPE E. D. 1895. - The classification of the ophidia. Transactions of the American Philosophical Society 18: 186-219. https://doi. org/10.2307/1005387

COPE E. D. 1879. - Eleventh contribution to the herpetology of tropical America. Proceedings of the American Philosophical Society 18 (104): 261-277. http://www.biodiversitylibrary.org/ page/7337315

CRABTREE P. J. 2016. — Zooarchaeology in Oceania: An overview. Archaeology in Oceania 51 (1): 1-6. https://doi.org/10.1002/ $\operatorname{arco.5089}$

Cundall D. \& IRISH F. 2008. - The snake skull, in Gans C., GAUNT A. S. \& AdLER K. (eds), The Skull of Lepidosauria. Society for the Study of Amphibians and Reptiles, New-York: 349-362.

Delpuech A., Hofman C. \& Hoogland M. 1997. - Fouilles sur le site précolombien de l'Anse à la Gourde (Saint-François, Guadeloupe). Journal de la Société des Américanistes 83 (1): 279-282.

Delpuech A., Hofman C. L. \& Hoogland M. L. P. 2001. - Excavations at the site of Anse à la Gourde, Guadeloupe. Organization, history and environmental setting, in Proceedings of the XVIIIth Congress for Caribbean Archaeology. IACA, Grenada: 156-161.

Delpuech A., Hofman C. L. \& Hoogland M. L. 2003. — Premiers horticulteurs amérindiens dans l'archipel Guadeloupéen: Morel I (Le
Moule) et la question Huecan/Cedrosan Saladoïde, in DeLPUECH A., GIRAUD J. P. \& Hesse A. (eds), Archéologie précolombienne et coloniale des Caraïbes, Actes du 123e Congrès national des sociétés historiques et scientifiques. Éditions du CTHS, Paris: 127-139.

De RocheforT C. D. 1658. - Histoire naturelle et morale des Îles Antilles de l'Amérique. Histoire générale des Antilles habitées par les Français. Arnould Liers, Rotterdam, 558 p. https://doi. org/10.5962/bhl.title.61244

De WaAl M. S. 2006. - Pre-Columbian Social Organization and Interaction Interpreted through the Study of Settlement Patterns: an Archaeological Case-Study of the Pointe des Chatteaux, La Désirade and les Iles de la Petite-Terre Micro-Region, Guadeloupe, F.W.I. Leiden University, Leiden, $419 \mathrm{p}$.

Du Tertre J.-B. (R. P.) 1654. - Histoire générale des isles de S. Christophe, de la Guadeloupe, de la Martinique, et autres dans l'Amérique. Chez Jacques Langlois et Emmanuel Langlois, Paris, 542 p. https://doi.org/10.5962/bhl.title.61174

Du TerTre J.-B. (R. P.) 1667. — Histoire générale des Antilles habitées par les François. T. Jolly, Paris, 551 p. https://doi.org/10.5962/ bhl.title. 119250

Duméril A. M. C., Bibron G. \& Duméril A. H. A. 1854. - Erpétologie générale ou histoire naturelle complète des reptiles, Tome VII. Librairie encyclopédique de Roret, Paris, 780 p. https://doi. org/10.5962/bhl.title.45973

ETHERIDGE R. 1964. - Late Pleistocene lizards from Barbuda, British West Indies. Bulletin of the Florida State Museum 9 (2): 43-76.

FitZINGER L. 1843. - Systema reptilium. Braumüller \& Seidel, Germany, 106 p. https://doi.org/10.5962/bhl.title.4694

FiTZPATRICK S. M. 2015. — The pre-columbian Caribbean: colonization, population dispersal, and island adaptations. PaleoAmerica 1 (4): 305-331. https://doi.org/10.1179/2055557115Y.0000000010

Fouéré P., Bailon S., Bonnissent D., Chancerel A., Courtaud P., Grouard S., Lenoble A., Mora P., Pinçon K. \& Queffelec A. 2011. - La grotte du Morne Rita (Commune de Capesterre de Marie-Galante, Guadeloupe). INRAP, Service régional de l'archéologie de Guadeloupe, Marie-Galante, Guadeloupe, 92 p.

Fouéré P., Chancerel A., Courtaud P., Grouard S., Lenoble A., Monney J., Mora P., Pinçon K., QuefFelec A. \& Tomadini N. 2012. - La grotte du Morne Rita (Commune de Capesterre de Marie-Galante, Guadeloupe). INRAP, Service régional de l'archéologie de Guadeloupe, Marie-Galante, Guadeloupe, 161 p.

Gagnepain J., Luzi C., SerRand N. \& Stouvenot C. 2007. Première approche du site de Caille à Bélasse: Campagne de 20062007. Direction régionale des affaires culturelle de Guadeloupe, Basse-Terre, Guadeloupe, 65 p.

GROUARD S. 1999. - Interprétations sur la présence des espèces de vertébrés et de crustacés du site de la Pointe du Helleux-GrandeTerre-Guadeloupe. True Blue, Grenada, $10 \mathrm{p}$.

GROUARD S. 2001 a. — Faunal remains associated with late Saladoïd and post-Saladoïd occupations at Anse à la Gourde, Guadeloupe, West Indies: Preliminary Results. Archaeofauna 10: 71-98.

GROUARD S. 2001b. - Subsistance, systèmes techniques et gestion territoriale en milieu insulaire antillais précolombien - Exploitation des Vertébrés et des Crustacés aux époques Saladoïdes et Troumassoïdes de Guadeloupe (400 av. J.-C. à 1500 ap. J.-C.). Université Paris X, Paris, 1073 p.

Grouard S., Debue K., Franel Y., Lenoble A., QuefFelec A. \& SERRAND N. 2014. - Abri de l'Anse à la Gourde, Saint-François, Grande-Terre (niveaux amérindiens et historiques), in Bilan Scientifique Guadeloupe 2010. Ministère de la Culture, Direction du Patrimoine, Sous-Dir. Archéologie, Paris, 59 p.

Hedges S. B. 1996. - Historical biogeography of West Indian vertebrates. Annual Review of Ecology and Systematics 27 (2): 163-196. https://doi.org/10.1146/annurev.ecolsys.27.1.163

Hedges S. B., Couloux A. \& Vidal N. 2009. - Molecular phylogeny, classification, and biogeography of West Indian racer snakes of the Tribe Alsophiini (Squamata, Dipsadidae, Xenodontinae). Zootaxa 2067: 1-28. 
HENDERSON R. 1992. - Consequences of predator introductions and habitat destruction on amphibians and reptiles in the post-columbus West Indies. Caribbean Journal of Science 28 (1-2): 1-10.

Henderson R. \& Powell R. 2009. - Natural History of West Indian Reptiles and Amphibians. University Press of Florida, Gainesville, 496 p.

HeNderson R. W. \& Bourgeois E. 1993. - Notes on the diets of West Indian Liophis (Serpentes: Colubridae). Caribbean Journal of Science 29: 253-254.

Henderson R. W. \& SajdaK R. A. 1996. - Diets of West Indian racers (Colubridae: Alsophis): composition and biogeographic implications, in POWEll R. \& HeNderson R. W. (eds), Contribution to West Indian herpetology: a Tribute to Albert Schwartz. Society for the Study of Amphibians and Reptiles, New-York:. 327-338.

HofFSTETTER R. \& GASC J. P. 1969. - Vertebrae and ribs of modern reptiles, in GANS C. (ed.), Biology of the Reptilia, Volume 1: Morphology. Academic Press, London: 201-310.

Hofman C. L. \& Hoogland M. L. P. 1994. - Le site de GrandeAnse (Terre-de-Bas, Les Saintes). Direction régionale des affaires culturelle de Guadeloupe, 17 p.

Hofman C. L., Hoogland M. L. P. \& Delpuech A. 1999. — New perspectives on a Huecan Saladoïd assemblage on Guadeloupe: the case of Morel I, in Hofman C. L. \& Hoogland M. L. P. (eds), Archaeological Investigations on St. Martin (Lesser Antilles). The sites of Norman Estate, Anse des Pères and Hope Estate, with a contribution to the "la Hueca problem". Leiden UniversityPress, Leiden: 303-312. http://hdl.handle.net/1887/13508

Holman J. A. 2000. — Fossil Snakes of North America: Origin, Evolution, Distribution, Paleoecology. Indiana University Press, Bloumington, $412 \mathrm{p}$.

Hoogland M. L. \& Hofman C. 1994. — Pointe du Helleux, site $n^{\circ}$ 97128001, (Guadeloupe, Sainte-Anne), prospection et sondages 1994. DRAC Guadeloupe, Service régional de l’Archéologie, 20 p.

HONORÉ S. 2014. - Évaluation du potentiel archéologique du site de l'Anse du Coq, Marie-Galante, Guadeloupe, in Actes du XXIVe Congrès de l'Association internationale d'Archéologie de la Caraïbe. AIAC, Fort-de-France: 240-248.

Hsiou A. S. \& Albino A. M. 2010. - New snake remains from the Miocene of northern South America. The Herpetological Journal 20 (4): 249-259.

Johnson C. N., Balmford A., Brook B. W., Buettel J. C., Galett M., GuANGCHUn L. \& WiLMShURST J. M. 2017. — Biodiversity losses and conservation responses in the Anthropocene. Science 356 (6335): 270-275. https://doi.org/10.1126/science.aam9317

KeEgan W. F., Hofman C. L. \& Ramos R. R. 2013. - The Oxford Handbook of Caribbean Archaeology. Oxford University Press, Oxford, 617 p. https://doi.org/10.1093/oxfordhb/9780195392302.001.0001

LASSERRE G. 1961. — La Guadeloupe: étude géographique. Tome 1: Le milieu naturel et l'héritage du passé. Union française d'impression, Bordeaux, $448 \mathrm{p}$.

Lauridsen H., Hansen K., Wang T., Agger P., Andersen J., Knudsen P. S., Rasmussen A. S., Uhrenholt L. \& Pedersen M. 2011. - Inside out: modern imaging techniques to reveal animal anatomy. PLoS ONE 6 (3). https://doi.org/10.1371/ journal.pone.0017879

LeNOBLE A. 2016. - Grotte des Bambous, Le Moule, in Bilan scientifique 2014 SRA Guadeloupe. Service régional de l'Archéologie, Direction régionale des affaires culturelles d'Ile-de-France, BasseTerre: 33-34.

Lenoble A., Grouard S., Cassagrande F., Serrand N. \& Romon T. 2008. - Faune fossile des cavités de Guadeloupe. Service régional de l'archéologie de Guadeloupe, Basse-Terre, Guadeloupe, 38 p.

Lenoble A., Grouard S., Fouéré P. \& Coutaud P. 2010. Cavités naturelles de Guadeloupe - aspects géologiques, fauniques et archéologiques. Service régional de l'Archéologie de Guadeloupe Direction régionale de l'Environnement de la Guadeloupe, Service Patrimoine de la Région Guadeloupe, Basse-Terre, 234 p.

LinNaEus C. 1758. - Systema Naturae per Regna tria Naturae, secundum Classes, Ordines, Genera, Species, cum characteribus, differentiis, synonymous, locis ed. 10. Volume 1. Laurentii Salvii, Holmiae, Stockholm, 828 p. https://doi.org/10.5962/bhl.title.559

MarX H. \& RABB G. B. 1972. - Phyletic analysis of fifty characters of advanced snakes. Field Museum of Natural History 63: 1-321. https://doi.org/10.5962/bhl.title.2981

Mead J. I. \& StEAdMan D. W. 2017. — Late Pleistocene snakes (Squamata: Serpentes) from Abaco, The Bahamas. Geobios 50 (5): 431-440. https://doi.org/10.1016/j.geobios.2017.09.001

Mosimann J. E. \& James F. C. 1979. - New Statistical Methods for Allometry with Application to Florida Red-Winged Blackbirds. Evolution 33 (1): 444-459. https://doi.org/10.2307/2407633

Münch P., Lebrun J.-F., CornéE J.-J., Thinon I., Guennoc P., MarCaillou B., Begot J., Bertrand G., Berc S. B. D. \& Biscarrat K. 2013. - Pliocene to Pleistocene carbonate systems of the Guadeloupe archipelago, French Lesser Antilles: a land and sea study (the KaShallow project). Bulletin de la Société géologique de France 184 (1): 99-110. https://doi.org/10.2113/gssgfbull.184.1-2.99

OpPeL M. 1811. — Die ordnungen, familien und gattungen der reptilien als prodrom einer naturgeschichte derselben. Joseph Lindauer, Munich, 87 p. https://doi.org/10.5962/bhl.title.4911

PARADIS E. \& SCHLIEP K. 2018. - Ape 5.0: an environment for modern phylogenetics and evolutionary analyses in R. Bioinformatics 35: 526-528. https://doi.org/10.1093/bioinformatics/ bty633

PARKER H. W. 1936. - Some extinct snakes of the West Indies. Annals and Magazine of Natural History 18 (104): 227-233. https://doi.org/10.1080/00222933608655187

Paulet-Locard M.-A. \& Stouvenot C. 2005. - Guadeloupe: Bilan et orientation de la recherche archéologique. Bilan Scientifique Régional 2005: 5-7.

PauleT-Locard M.-A. \& Chancerel A. 2005. - Basse-Terre, Gare Maritime, Diagnostic archeologique. SRA Guadeloupe, 15 p.

POWELL R. \& HENDERSON R. W. 2012. - Island list of West Indian amphibians and reptiles. Bulletin of Florida Museum of Natural History 51 (2): 85-166.

Pregill G. K., Steadman D. W., Olson S. L. \& Grady F. V. 1988. - Late Holocene fossil vertebrates from Burma Quarry, Antigua, Lesser Antilles. Smithsonia Contribution to Zoology 463: 1-27. https://doi.org/10.5479/si.00810282.463

Rage J. C. 1984. - Serpentes, in Handbuch der Paläoherpetologie. Volume 11. Gustav Fischer, Stuttgart, 80 p.

Rage J. C. 2001. - Fossil snakes from the Palaeocene of São Jose de Itaborai, Brazil. Part 2. Boidae. Palaeovertebrata 30 (3-4): 111-150.

Ripley B., Venables B., Bates D. M., Hornick K., Gebhardt A. \& FIRTH D. 2016. - MASS: Support Functions and Datasets for Venables and Ripley's MASS. https://rdrr.io/cran/MASS/

ROMON T. 2001. - Cathédrale de Basse-Terre (Guadeloupe). AFAN Grand sud-ouest, SRA Guadeloupe, DRAC.

Romon T., Bertran P., Fouéré P., Hildebrand M., Serrand N. \& VALLET C. 2006. — Fouille préventive de la gare maritime de Basse-Terre. INRAP, Service régional de l'archéologie de Guadeloupe, Basse-Terre, $457 \mathrm{p}$.

Royer A., Malaizé B., Lécuyer C., QuefFelec A., Charlier K., Caley T. \& Lenoble A. 2017. - A high-resolution temporal record of environmental changes in the Eastern Caribbean (Guadeloupe) from 40 to $10 \mathrm{ka} \mathrm{BP.} \mathrm{Quaternary} \mathrm{Science} \mathrm{Reviews}$ 155: 198-212. https://doi.org/10.1016/j.quascirev.2016.11.010 Saunders N. J. 2005. - The Peoples of the Caribbean: an Encyclopedia of Archaeology and Traditional Culture. ABC CLIO, Denver, 423 p.

SCHLEGEL H. 1837. - Essai sur la physionomie des serpents - Partie descriptive. M. H. Schonekat, Libraire-Editeur, Amsterdam, 606 p. https://doi.org/10.5962/bhl.title.4273

Serrand N., Bonnissent D., Fouilloud C., Sellier-Segard N. \& Audouit F. 2010. - Tourlourous, Stade josé Bade. INRAP, Service régional de l'archéologie de Guadeloupe, Marie-Galante, 64 p.

Siegel P. E., Jones J. G., Pearsall D. M., Dunning N. P., Farrell P., Duncan N. A., Curtis J. H. \& Singh S. K. 2015. - 
Paleoenvironmental evidence for first human colonization of the eastern Caribbean. Quaternary Science Reviews 129: 275-295. https://doi.org/10.1016/j.quascirev.2015.10.014

Steadman D. W., Albury N. A., KaKuk B., Mead J. I., SotoCenteno J. A., Singleton H. M. \& Franklin J. 2015. - Vertebrate community on an ice-age Caribbean island. Proceedings of the National Academy of Sciences 112 (44): E5963-E5971. https://doi.org/10.1073/pnas.1516490112

Steadman D. W., Pregill G. K. \& Olson S. L. 1984. - Fossil vertebrates from Antigua, Lesser Antilles: evidence for late Holocene human-caused extinctions in the West Indies. Proceedings of the National Academy of Sciences of the United States of America 81: 4448-4451. https://doi.org/10.1073/pnas.81.14.4448

Stoetzel E., Royer A., Cochard D. \& Lenoble A. 2016. Late Quaternary changes in bat palaeobiodiversity and palaeobiogeography under climatic and anthropogenic pressure: new insights from Marie-Galante, Lesser Antilles. Quaternary Science Reviews 143: 150-174. https://doi.org/10.1016/j.quascirev.2016.05.013

Stouvenot C., Grouard S., Bailon S., Bonnissent D., LenoBle A., Serrand N. \& Sierpe V. 2014. - L'abri sous roche Cadet 3 (Marie-Galante): un gisement à accumulations de faune et à vestiges archéologiques, in BÉRARD B. \& LOSIER C. (eds), Archéologie Caraïbe. Sidestone Press, Leiden: 77-102.

SZYNDLAR Z. 1984. - Fossil snakes from Poland. Acta Zoologica Cracoviensia 1 (28): 1-156.

UNDERWOOD G. 1993. - A new snake from St Lucia, West Indies. Bulletin of the Natural History Museum (Zool.) 59: 1-9. http:// www.biodiversitylibrary.org/page/41149592

VIGNE J.-D. 1992. — Zooarchaeology and the biogeographical history of the mammals of Corsica and Sardinia since the last ice age. Mammal Review 22 (2): 87-96. https://doi. org/10.1111/j.1365-2907.1992.tb00124.x

WaGLER J. 1830. - Natürliches System der Amphibien, mit vorangehender Classification der Säugthiere und Vögel. Cotta, Munich, Stuttgart, Tübingen, 354 p. https://doi.org/10.5962/ bhl.title. 58730

Zanette I., Daghfous G., Weitkamp T., Gillet B., Adriaens D., Langer M., Cloetens P., Helfen L., Bravin A., Peyrin F., Baumbach T., Dischler J.-M., Loo D. V., Praet T., PoiRIER-QUINOT M. \& BOISTEL R. 2013. — Looking inside marine organisms with magnetic resonance and x-ray imaging, in REYNAUD EG. (ed.), Imaging Marine Life. Wiley-VCH, Weinheim: 122-184. https://doi.org/10.1002/9783527675418.ch7

\section{APPENDICES}

APPENDIX 1. - List of extant comparative specimens used. Abbreviations: MCZ, Museum of Comparative Zoology (Boston, Massachusetts; UF, Florida Museum of Natural History (Gainesville, Florida; MNHN-RA, Muséum national d'Histoire naturelle, herpetology collection (Paris); MNHN-ZA-AC, Muséum national d'Histoire naturelle, comparative anatomy collection (Paris); coll. UMR7209, Muséum national d'Histoire naturelle, UMR 7209 laboratory collection (Paris).

Alsophis antillensis (Schlegel, 1837) (unknown variety): MCZ R-29785; MCZ R-42181; MCZ R-61072; MCZ R-61073. Alsophis antillensis ("A variety"): coll. UMR7209 601.

Alsophis rijgersmaei Cope, 1869: MNHN-ZA-AC 2016-9; coll. UMR7209 406.

Alsophis rufiventris: MCZ R-6129; MCZ R-6130; MCZ R-76665; UF 15495.

Clelia clelia: MNHN-RA-1989.3087.

Erythrolamprus juliae mariae: MCZ R-6138; MCZ R-32055; MCZ R-177411.

Erythrolamprus juliae juliae: MCZ R-57819.

Erythrolamprus juliae copeae: MNHN-RA-1998.485.

Erythrolamprus perfuscus (Cope, 1862): MCZ R-78619; MCZ R-78620. 
APPENDIX 2. - List of the studied sites that have yielded fossils of dipsadid snakes on the Guadeloupe Islands, with their names, type of deposit, cultural attribution. Archaic, 2000-500 BC; Early Saladoid, 500 BC-500 AD; Late Saladoid, 500-850 AD; Early Troumassoid, 750-1000 AD; Late Troumassoid, 1000-1600 AD; Colonial Modern, XV-XVIII century; Contemporary, XIX century-Present day. Excavation director: RE, rescue excavations; PE, programmed excavations, D, diagnostic [year], and main publications and/or unpublished reports.

\begin{tabular}{|c|c|c|c|c|c|}
\hline Island & Site & Type of deposit & Cultural period & Excavation & Reference \\
\hline Les Saintes & $\begin{array}{l}\text { Grande-Anse de } \\
\text { Terre de Bas }\end{array}$ & Archaeological & Late Troumassoid & Hofman \& Hoogland (RE) [1994] & $\begin{array}{l}\text { Hofman \& Hoogland } \\
1994\end{array}$ \\
\hline \multirow[t]{7}{*}{$\begin{array}{l}\text { Grande- } \\
\text { Terre }\end{array}$} & Anse à la Gourde & Archaeological & $\begin{array}{l}\text { Late Saladoid-Early \& } \\
\text { Late Troumassoid }\end{array}$ & $\begin{array}{l}\text { Delpuech, Hofman \& Hoogland } \\
\text { (PE) [1995-2002] }\end{array}$ & $\begin{array}{l}\text { Delpuech et al. 1997; } \\
\text { Hofman et al. 1999; } \\
\text { Delpuech et al. 2001; } \\
\text { Grouard 2001a; Beets } \\
\text { et al. } 2006\end{array}$ \\
\hline & $\begin{array}{l}\text { Anse à la Gourde } \\
\text { Cave }\end{array}$ & Natural & Colonial Modern & Grouard (PE) [2010] & Grouard et al. 2014 \\
\hline & Anse à l'Ecu Cave & Natural & Colonial Modern & Lenoble (PE) [2009] & Lenoble et al. 2010 \\
\hline & Bambous Cave & Natural & Colonial Modern & Lenoble (PE) [2014] & Lenoble 2016 \\
\hline & Morel & Archaeological & $\begin{array}{l}\text { Early Saladoid (Morel I, } \\
\text { II) - Troumassoid (Morel } \\
\text { III, IV) }\end{array}$ & $\begin{array}{l}\text { Clerc (PE) [1964]; Delpuech, } \\
\text { Hofman \& Hoogland (RE) [1999] }\end{array}$ & $\begin{array}{l}\text { Hofman et al. 1999; } \\
\text { Delpuech et al. } 2003\end{array}$ \\
\hline & Pointe du Helleux & Archaeological & Late Troumassoid & $\begin{array}{l}\text { Hoogland \& Hofman (RE) [1994], } \\
\text { [1997] }\end{array}$ & $\begin{array}{l}\text { Hoogland \& Hofman } \\
\text { 1994; Grouard } 1999\end{array}$ \\
\hline & Trou Lolo & Natural & Colonial Modern & Lenoble (PE) [2008] & Lenoble et al. 2008 \\
\hline \multirow[t]{3}{*}{ Basse-Terre } & $\begin{array}{l}\text { Cathédrale de } \\
\text { Basse-Terre }\end{array}$ & Archaeological & Early Saladoid & $\begin{array}{l}\text { Romon (D) [2001]; Bonnissent \& } \\
\text { Romon (RE) [2002] }\end{array}$ & $\begin{array}{l}\text { Romon 2001; } \\
\text { Bonnissent \& Romon } \\
2004\end{array}$ \\
\hline & $\begin{array}{l}\text { Gare Maritime de } \\
\text { Basse-Terre }\end{array}$ & Archaeological & Early Saladoid & $\begin{array}{l}\text { Paulet-Locart and Chancerel (D) } \\
\text { [2005]; Romon (RE) [2006] }\end{array}$ & $\begin{array}{l}\text { Paulet-Locard \& } \\
\text { Chancerel 2005; } \\
\text { Romon et al. } 2006\end{array}$ \\
\hline & $\begin{array}{l}\text { Sainte-Rose La } \\
\text { Ramée }\end{array}$ & Archaeological & Early Troumassoid & Casagrande (RE) [2006] & Casagrande et al. 2010 \\
\hline \multirow[t]{2}{*}{ La Désirade } & Petite Rivière & Archaeological & $\begin{array}{l}\text { Late Saladoid -Early } \\
\text { Troumassoid }\end{array}$ & Bodu (RE) [1984] ; de Waal [1995] & $\begin{array}{l}\text { Bodu 1984; Bodu 1985; } \\
\text { de Waal } 2006\end{array}$ \\
\hline & $\begin{array}{r}\text { Pointe Gros } \\
\text { Rempart } 6\end{array}$ & Archaeological & Colonial Modern & Boudadi-Maligne (PE) [2011] & $\begin{array}{l}\text { Boudadi-Maligne et al. } \\
2016\end{array}$ \\
\hline $\begin{array}{l}\text { Petite-Terre } \\
\text { islets }\end{array}$ & Caille à Bélasse & Archaeological & Late Troumassoid & Gagnepain (PE) [2006-2007] & Gagnepain et al. 2007 \\
\hline \multirow[t]{6}{*}{$\begin{array}{l}\text { Marie- } \\
\text { Galante }\end{array}$} & Cadet 2 Cave & $\begin{array}{l}\text { Natural/ } \\
\text { Archaeological }\end{array}$ & Late Troumassoid & $\begin{array}{l}\text { Courtaud (PE) [2005]; Grouard (PE) } \\
\text { [2010] }\end{array}$ & Bochaton et al. 2015 \\
\hline & Abri Cadet 3 & $\begin{array}{l}\text { Natural/ } \\
\text { Archaeological }\end{array}$ & $\begin{array}{l}\text { Archaic, Late } \\
\text { Troumassoid }\end{array}$ & Stouvenot (PE) [2007] & Stouvenot et al. 2014 \\
\hline & Blanchard Cave & $\begin{array}{l}\text { Natural/ } \\
\text { Archaeological }\end{array}$ & $\begin{array}{l}\text { Pleistocene-Late } \\
\text { Troumassoid }\end{array}$ & $\begin{array}{l}\text { Lenoble (PE) [2008 \& Courtaud } \\
\quad(P E)[2011]\end{array}$ & $\begin{array}{l}\text { Bailon et al. 2015; } \\
\text { Stoetzel et al. 2016; } \\
\text { Royer et al. } 2017\end{array}$ \\
\hline & Morne Rita Cave & Archaeological & Archaic Saladoid & Fouéré (PE) [2011-2014] & $\begin{array}{l}\text { Fouéré et al. 2011; } \\
\text { Fouéré et al. 2012; }\end{array}$ \\
\hline & $\begin{array}{l}\text { Jean-François } \\
\text { gully Cave }\end{array}$ & Archaeological & Colonial Modern & Lenoble (PE) [2010] & Lenoble et al. 2010 \\
\hline & $\begin{array}{l}\text { Tourlourous - } \\
\text { Stade José Bade }\end{array}$ & Archaeological & $\begin{array}{l}\text { Late Saladoid-Early and } \\
\text { Late Troumassoid }\end{array}$ & $\begin{array}{l}\text { Colas (RE) [2002]; Serrand (RE) } \\
\text { [2010; 2012] }\end{array}$ & $\begin{array}{l}\text { Colas et al. 2002; } \\
\text { Serrand et al. } 2010\end{array}$ \\
\hline
\end{tabular}

